\title{
Cell-Surface Glycoprotein of Oligodendrocyte Progenitors Involved in Migration
}

\author{
Antje Niehaus, Judith Stegmüller, Marianne Diers-Fenger, and Jacqueline Trotter \\ Department of Neurobiology, University of Heidelberg, 69120 Heidelberg, Germany
}

Myelination by oligodendrocytes in the CNS involves the migration to and recognition and ensheathment of axons. These distinct developmental phases of myelination are assumed to involve the interplay of a precisely regulated set of cell adhesion molecules expressed by both neurons and glial cells. These molecules remain largely unelucidated. In this paper we have identified a large (330 kDa) glycoprotein expressed by murine oligodendrocyte progenitor cells in vitro and in vivo that is downregulated as oligodendrocytes mature. Antigen-positive oligodendrocyte progenitor cells purified by panning develop into myelin-associated glycoprotein-positive oligodendrocytes and also adhere to cultured neurons. Polyclonal antibodies directed against the protein reduce the migration of oligodendrocyte progenitor cells. The observations suggest that the AN2 antigen may play a role in early stages of myelination.

Key words: oligodendroglial precursor; migration; cellsurface protein; neurite outgrowth; myelination; glycoprotein
The myelination of CNS axons by oligodendrocytes is essential for conduction of the action potential. Oligodendrocytes develop from progenitor cells located in the ventricular (VZ) and subventricular zone (SVZ) of the brain (Reynolds and Wilkin, 1988; Levison and Goldman, 1993; Hardy and Friedrich, 1996) and spinal cord (Noll and Miller, 1993; Pringle and Richardson, 1993). To reach the axonal tracts that are myelinated in the late embryonic and early postnatal period, the cells must migrate over extensive distances. Migration of oligodendrocyte-lineage cells out of transplants of CNS tissue (Lachapelle et al., 1983-1984) or of immunoisolated cells (Warrington et al., 1993) has been elegantly demonstrated in shiverer mutant mice. In addition, studies on early postnatal mouse brain using retroviral labeling have demonstrated the development of oligodendrocytes from cells that have migrated out of the SVZ (Levison and Goldman, 1993). This migration occurs over the surface of astrocytes, extracellular matrix (ECM) molecules, and in some cases, for example in the optic nerve, also along axonal tracts (Small et al., 1987; Ono et al., 1997). Myelination ensues after recognition of the axon by the progenitor cells, followed by the ensheathment of the axon by oligodendrocyte processes and synthesis of the compacted myelin. This cell-cell interaction is specific: only larger-diameter axons and not dendrites are myelinated (Lubetzki et al., 1993), and the upregulation of the expression of myelin genes by the oligodendrocyte is under strict temporal control. The axonal surface plays a pivotal instructive role in determining where and when myelination occurs. Each of these specific interactions dur-

\footnotetext{
Received Dec. 18, 1998; revised March 31, 1999; accepted April 1, 1999.

This work was supported by the Deutsche Forschungsgemeinschaft (Glia Schwerpunkt, to J.T.) and the Danish Research Academy (M.D.-F.). We thank Drs. C. Lagenauer (M5) and R. Reynolds (LB1) for kind gifts of antibodies. The excellent technical assistance of I. Bünzli-Ehret and D. Kendel is gratefully acknowledged. Dr. G. Sawitzki is thanked for advice on statistics. A.N. was a member of the graduate program "Molecular and Cellular Neurobiology" of the University of Heidelberg. Dr. Matthew Hannah and Stephanie Schneider are thanked for critical reading of this manuscript.

Correspondence should be addressed to Jacqueline Trotter, Department of Neurobiology, University of Heidelberg, Im Neuenheimer Feld 364, 69120 Heidelberg, Germany.

Copyright (C) 1999 Society for Neuroscience $\quad 0270-6474 / 99 / 194948-14 \$ 05.00 / 0$
}

ing migration and axonal ensheathment must involve the interplay between specific cell adhesion molecules (CAMs) located on the axonal surface, the migration substrate, and the oligodendroglial precursor cells (Doyle and Colman, 1993; Pfeiffer et al., 1993).

The identity of these molecules remains largely undetermined. Recent work has shown that integrins are expressed by oligodendroglial cells (Malek-Hedayat and Rome, 1994; Milner and ffrench-Constant, 1994) and are involved in regulating migration of the precursor cells on extracellular matrix molecules (Milner et al., 1996). The myelin-associated glycoprotein (MAG) is essential for the maintenance of the mature myelinated unit (Li et al., 1994; Montag et al., 1994; Fruttiger et al., 1995). In the PNS, the molecules L1, N-CAM, and MAG, which are expressed by Schwann cells, are involved in initial glial-axon interactions (Seilheimer et al., 1989; for review, see Martini and Schachner, 1997). Similarly, in the CNS an array of cell adhesion molecules expressed by the myelinating glial cell are likely to be involved in regulating migration and axonal adhesion.

To identify molecules playing a role in these early phases of myelination, we generated monoclonal antibodies against a murine oligodendroglial precursor cell line (Oli-neu) (Jung et al., 1995) that specifically recognizes and ensheathes demyelinated axons. One antibody recognizes a large $(330 \mathrm{kDa})$ surface protein (AN2) that is expressed by proliferative, migratory progenitor cells and downregulated with differentiation. Our results suggest that this protein plays a role in migration of oligodendrocyte precursors.

\section{MATERIALS AND METHODS}

Material. ${ }^{125}$ I-labeled protein A was from Amersham-Buchler (Braunschweig, Germany), polyvinylidene difluoride membrane was from Millipore Corporation (Bedford, MA), and protease inhibitors (PMSF, aprotinin, pepstatin, amino- $n$-caproic acid, antipain, leupeptin, soybean trypsin inhibitor, benzamidine) were purchased from Sigma (Deisenhofen, Germany). Octyl- $\beta$-glycopyranoside (octylglucoside) was from AppliChem (Darmstadt, Germany); chondroitinase ABC, $N$-glycosidase $\mathrm{F}$, neuraminidase, $O$-glycosidase, bovine serum albumin (BSA), swainsonine, trypsin (sequencing grade), tunicamycin, and laminin were purchased from Boehringer Mannheim (Mannheim, Germany). 
Antibodies. The following antibodies were used: mouse monoclonal antibody LB1, directed against the molecule GD3 recognizing glial precursor cells and an early stage of neuroectodermal cells (Reynolds and Wilkin, 1988) (a kind gift of Dr. R. Reynolds); mouse monoclonal antibody $\mathrm{O} 4$ recognizing late glial precursor cells, oligodendrocytes, and Schwann cells (Schachner et al., 1981; Sommer and Schachner, 1981; Trotter and Schachner, 1989); affinity-purified rabbit polyclonal antibody against L1, specific for neurons (Rathjen and Schachner, 1984); mouse monoclonal antibody 513 against MAG (Poltorak et al., 1987); rabbit polyclonal antibody against MAG (a kind gift of Dr. F. Kirchoff); rabbit polyclonal antibody against GFAP (Dakopatts, Hamburg, Germany); rat monoclonal antibody M5 recognizing neurons (Keilhauer et al., 1985) (a kind gift of Dr. C. Lagenauer); rabbit polyclonal antibody specific for the PDGF- $\alpha$-receptor (C-20, Santa Cruz Biotechnology, Heidelberg, Germany); mouse monoclonal antibody against MAP-2 (Clone AP20, Boehringer Mannheim, Mannheim, Germany); mouse monoclonal antibody against $\beta$-III tubulin (Clone SDL.3D10, Sigma); mouse monoclonal antibody DM $1 \mathrm{~A}$ against $\alpha$-tubulin (Clone DM1A, Sigma); rat monoclonal antibody 412 against the L2/HNK-1 carbohydrate epitope (Krüse et al., 1984); Mac-1 (Springer et al., 1979) and F4/80 (Austyn and Gordon, 1981) monoclonal antibodies recognizing microglia; polyclonal antibodies against an N-terminal peptide of the F3 adhesion molecule expressed by neurons and oligodendrocyte lineage cells (Koch et al., 1997). Secondary polyclonal antibodies were purchased from Dianova (Hamburg, Germany).

Animals. NMRI mice of both sexes were obtained from the central animal facilities of the University of Heidelberg. Female Lou x Sprague Dawley rats and New Zealand rabbits were used for the preparation of monoclonal and polyclonal antibodies, respectively.

Cell culture. Primary cultures of enriched oligodendrocytes and their precursor cells were established from brains of 15-d-old NMRI mouse embryos (Trotter et al., 1989) after removal of neurons by immunocytolysis with M5 antibody and complement. Oligodendrocytes and precursor cells were shaken off as described.

Cultures of mixed brain cells were established from E14 mouse embryos basically according to Schnitzer and Schachner (1981). The cells were cultured in Eagle's basal medium (BME)/10\% horse serum (HS). Highly pure populations of cerebellar granule cells were generated from P6 murine cerebella cells by isolation on Percoll gradients (Pharmacia, Freiburg, Germany) as described by Keilhauer et al. (1985).

Cultures of dorsal root ganglion neurons were established from postnatal day (P) 0-1 mice according to Seilheimer and Schachner (1988). The neurons were enriched by flotation on a $35 \%$ Percoll gradient and subsequently plated on laminin-coated coverslips in BME/10\% HS plus $200 \mathrm{ng} / \mathrm{ml}$ NGF. To eliminate the possibility of contaminating nonneuronal cells, $50 \mu \mathrm{M}$ cytosine arabinoside (Ara C, Calbiochem, Bad Soden, Germany) was added to the medium. After 5-7 d the Ara C was left out of the medium, and the neuronal cultures used in co-culture experiments.

Immunofluorescence. Stainings of cultures for indirect immunofluorescence were performed as described by Schnitzer and Schachner (1981). For staining of sections, brains from embryonic and early postnatal mice were fixed in $4 \%$ paraformaldehyde (PFA), $4 \%$ sucrose at $4{ }^{\circ} \mathrm{C}$ overnight, washed twice in PBS followed by 3-4 hr cryoprotection in $0.5 \mathrm{M}$ sucrose at $4^{\circ} \mathrm{C}$, and embedded in Tissue Tek (OCT compound, Miles Inc.). Adult mice were anesthetized with nembutal $(82 \mathrm{mg} / \mathrm{kg})$ and perfused with $4 \%$ PFA in PBS by injection into the left ventricle. Brains were removed, post-fixed for $2-3 \mathrm{hr}$ in $4 \%$ PFA in PBS at $4^{\circ} \mathrm{C}$, cryoprotected in $0.9 \mathrm{M}$ sucrose overnight, and embedded. Cryosections of $8 \mu \mathrm{m}$ were cut and allowed to dry. After permeabilization for $15 \mathrm{~min}$ in $0.5 \%$ Triton X-100 in PBS, sections were washed three times for $5 \mathrm{~min}$ in PBS, quenched in $50 \mathrm{mM} \mathrm{NH}_{4} \mathrm{Cl}$ in PBS for $15 \mathrm{~min}$, washed in PBS, blocked in $1 \%$ BSA, $5 \%$ FCS in PBS for 30 min, and incubated with primary antibody in blocking solution at $4^{\circ} \mathrm{C}$ overnight. The sections were then washed and incubated with secondary antibody (Cy3-conjugated goat anti-rat for AN2, and FITC-conjugated goat anti-rabbit for PDGF- $\alpha$-receptor) for $30 \mathrm{~min}$ in blocking solution, washed, rinsed briefly in water, and mounted in Moviol (Hoechst, Frankfurt, Germany).

Generation of the AN2 monoclonal antibody. Rats were immunized with $4-5 \times 10^{7}$ Oli-neu cells three times at intervals of 3 weeks. The cells were cultured in serum-free Sato medium for $24 \mathrm{hr}$ before release from the culture dishes with $0.25 \%$ EDTA. The washed cells were irradiated with $3000 \mathrm{Rad}$ to prevent formation of a tumor and injected under the skin. Fusion of the spleen cells of the immunized animal with the myeloma line X63Ag8.653 was performed $4 \mathrm{~d}$ after the last immunization according to Faissner and Kruse (1990). Positive clones were selected by surface staining of cells of the Oli-neu cell line and primary oligodendrocytes, followed by Western blot analysis. Single-cell clones of interesting hybridomas were isolated by limiting dilution using irradiated mouse spleen cells as feeder cells. One of the selected clones was AN2 1E6, which produced an antibody of the IgG1 subclass. The antibody was purified by ammonium sulfate precipitation from hybridoma supernatant of cells growing in serum-free medium containing nutridoma (Boehringer Mannheim).

Isolation of the AN2 antigen by affinity chromatography. Brain tissue $(10-25 \mathrm{gm})$ from P9-P10 mice was homogenized in $1 \mathrm{~mm} \mathrm{NaHCO}, 0.2$ $\mathrm{mm} \mathrm{CaCl} 2,0.2 \mathrm{~mm} \mathrm{MgCl}_{2}, 1 \mathrm{~mm}$ spermidine (Serva, Heidelberg, Germany), and protease inhibitors ( $1 \mathrm{~mm}$ PMSF, $0.1 \mu \mathrm{g} / \mathrm{ml}$ pepstatin, 100 $\mathrm{mm}$ amino- $n$-caproic acid, $1 \mu \mathrm{g} / \mathrm{ml}$ antipain, $1 \mu \mathrm{g} / \mathrm{ml}$ aprotinin, $2 \mathrm{~mm}$ EDTA, $2 \mathrm{~mm}$ EGTA, $5 \mu \mathrm{g} / \mathrm{ml}$ leupeptin, $10 \mu \mathrm{g} / \mathrm{ml}$ soybean trypsin inhibitor, $0.26 \mathrm{mg} / \mathrm{ml}$ benzamidine). The suspension was then centrifuged at $200 \times g$ at $4^{\circ} \mathrm{C}$ for $20 \mathrm{~min}$, and the sediment was extracted an additional three times with homogenization buffer. The combined supernatants were centrifuged at $100,000 \times g$ for $1 \mathrm{hr}$. To remove nonintegral membrane proteins, the sediment was suspended in $0.1 \mathrm{M} \mathrm{Na}_{2} \mathrm{CO}_{3}, \mathrm{pH}$ $11.5,1 \mathrm{mg} / \mathrm{ml}$ saponin (Sigma, München, Germany), $5 \mathrm{~mm}$ EDTA, and protease inhibitors and incubated for $30 \mathrm{~min}$ at $4^{\circ} \mathrm{C}$. The $100,000 \times g$ centrifugation step was then repeated, and the pellet was incubated for 1 hr at $4^{\circ} \mathrm{C}$ in $150 \mathrm{~mm} \mathrm{NaCl}, 20 \mathrm{~mm}$ Tris/ $\mathrm{HCl}, \mathrm{pH}$ 7.4, $1 \mathrm{~mm}$ EDTA, $1 \mathrm{~mm}$ EGTA, protease inhibitors, and $0.5 \%$ NP-40 (Sigma). The nonsolubilized material was separated by an additional $100,000 \times g$ centrifugation step and subsequently extracted with $150 \mathrm{~mm} \mathrm{NaCl}, 20 \mathrm{~mm}$ Tris/ $\mathrm{HCl} \mathrm{pH}$ 7.4, $1 \mathrm{~mm}$ EDTA, $1 \mathrm{~mm}$ EGTA, and $8 \mathrm{mg} / \mathrm{ml}$ octylglucoside and protease inhibitors. The pellet from a final $100,000 \times g$ centrifugation step was discarded. Purified AN2-antibody was coupled to cyanogen bromideactivated Sepharose (Pharmacia) following the manufacturer's instructions. The combined supernatants from the NP-40 and octylglucoside extraction steps were applied to the antibody column that had been equilibrated with $150 \mathrm{~mm} \mathrm{NaCl}, 20 \mathrm{~mm}$ Tris/HCl, pH 7.4, 1 mm EDTA, $1 \mathrm{~mm}$ EGTA, and $0.5 \% \mathrm{NP}-40$. After the application the column was washed with $10 \mathrm{vol}$ of $300 \mathrm{~mm} \mathrm{NaCl}, 20 \mathrm{~mm}$ Tris/ $\mathrm{HCl}, \mathrm{pH} 7.4,1 \mathrm{~mm}$ EDTA, 1 mM EGTA, and $0.5 \%$ NP-40, and subsequently with 3 column vol of PBS with $8 \mathrm{mg} / \mathrm{ml}$ octylglucoside, and the bound antigen was then eluted with 4 vol of $0.1 \mathrm{M}$ diethylamine, $\mathrm{pH}$ 11.5, $1 \mathrm{~mm}$ EDTA, $1 \mathrm{~mm}$ EGTA, and $10 \mathrm{mg} / \mathrm{ml}$ octylglucoside. The eluate volume was reduced to 3-5 ml by ultrafiltration with an XM300 filter (Amicon, Witten, Germany) and dialyzed twice against $100 \mathrm{ml}$ PBS with $8 \mathrm{mg} / \mathrm{ml}$ octylglucoside. Purified antigen was used fresh or stored at $-80^{\circ} \mathrm{C}$.

Generation of polyclonal antibodies against the AN2 antigen. Pure antigen $(50-100 \mathrm{mg}$ ) was mixed with an equal volume of Freund's Adjuvant and injected subcutaneously at 3 week intervals in several sites on the back of New Zealand rabbits. Blood was taken $10 \mathrm{~d}$ after the third and subsequent immunizations, and when a sufficient titer had been reached, the IgG fraction was isolated by chromatography on Protein A-Sepharose (Pharmacia), according to the manufacturer's instructions. The polyclonal IgG antibodies against F3 used as a control (Koch et al., 1997) were also purified by chromatography over Protein A.

Immunoselection of AN2-positive cells from shaken-off oligodendrocytes by "panning." To isolate AN2-positive cells by panning, the method of Wysocki and Sato (1978) as modified by Barres et al. (1992) was used. Bacteriological Petri dishes were coated at $4^{\circ} \mathrm{C}$ overnight with $10 \mu \mathrm{g} / \mathrm{ml}$ rabbit anti-rat antibody in $0.05 \mathrm{M}$ Tris $/ \mathrm{HCl}, \mathrm{pH} 9.5$. The plates were washed three times with PBS and incubated for $30 \mathrm{~min}$ at room temperature with PBS plus $10 \%$ HS. The suspension of shaken-off oligodendrocytes and their progenitor cells (see above; $2-4 \times 10^{7}$ cells total) was incubated for $20 \mathrm{~min}$ at $4^{\circ} \mathrm{C}$ with the monoclonal AN2 antibody. The washed cells were then added to the Petri dishes and incubated for 90 min at $4^{\circ} \mathrm{C}$. Nonadherent cells were removed by several vigorous washing steps at $4^{\circ} \mathrm{C}$, and the adherent cells were released from the plate with $0.01 \%$ trypsin $/ 0.02 \%$ EDTA in calcium-free, magnesium-free HBSS. The released cells (roughly $10 \%$ of the total cells applied) were plated onto poly-L-lysine (pLL)-coated coverslips in Sato/1\% HS plus $50 \%$ astrocyteconditioned medium (medium from astrocytes cultured in Sato/1\% HS for $24 \mathrm{hr}$ ) to permit survival. After $4-6 \mathrm{hr}, 1,2$, and $5 \mathrm{~d}$ in culture, the coverslips were stained with AN2 and MAG, O4, O1, or GFAP antibodies. Alternatively, the cells were added to the dorsal root ganglion neurons, and the co-culture (for $24 \mathrm{hr}$ ) was performed in Sato/1\% HS plus $20 \mathrm{ng} / \mathrm{ml} \mathrm{NGF}$.

Preparation of brain lysates. Samples of brain were homogenized in ice-cold homogenization buffer (PBS, $60 \mathrm{~mm}$ octylglucoside containing 

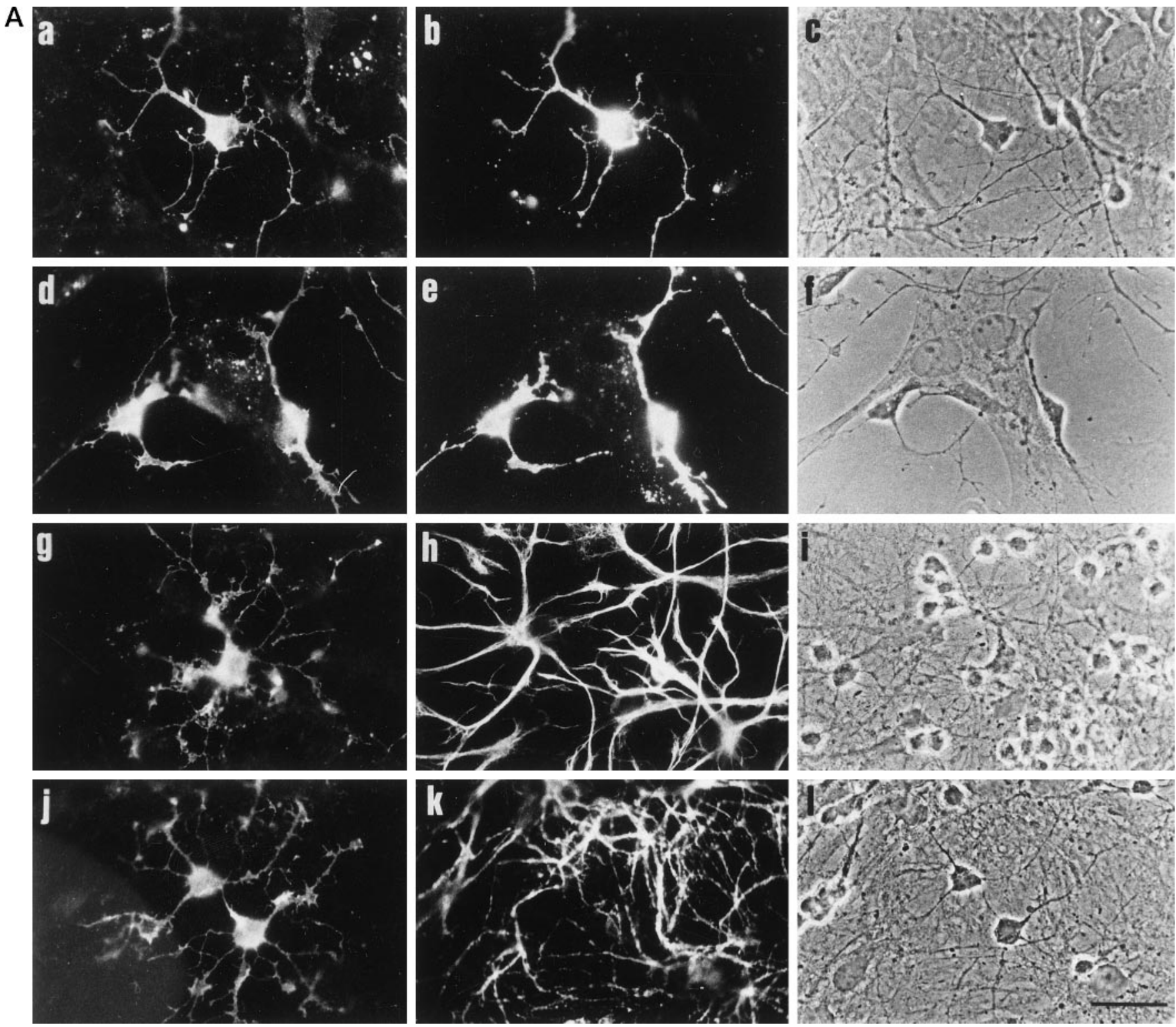

Figure 1. Expression of the AN2 antigen within the oligodendrocyte lineage. $A$, Staining of oligodendrocyte progenitor cells by the AN2 antibody in cultures of E14 murine brain. After $10 \mathrm{~d}$ in culture, cells growing on glass coverslips were stained by double immunofluorescence with the following antibodies: AN2 $(a, d, g, j), \mathrm{O} 4(b), \mathrm{LB} 1(e), \operatorname{GFAP}(h), \mathrm{L} 1(k)$; corresponding phase-contrast pictures are in $c, f, i$, and $l$. Scale bar, $29 \mu \mathrm{m}$. (Figure continues.)

protease inhibitors) with 10 strokes in a glass-Teflon homogenizer. The extract was shaken for $1 \mathrm{hr}$ at $4^{\circ} \mathrm{C}$. Insoluble material was separated by centrifugation $\left(10 \mathrm{~min}, 3000 \times g\right.$ at $\left.4^{\circ} \mathrm{C}\right)$, the protein content of the supernatant was determined with a Bio-Rad protein assay (Bio-Rad, München, Germany), and 100-200 $\mu \mathrm{g}$ protein per lane of a polyacrylamide gel was analyzed by Western blotting.

Gel electrophoresis and immunoblotting. SDS-PAGE was performed according to Laemmli (1970) using 4-10\% gradient gels. Proteins were visualized with silver staining or Coomassie blue. Proteins blotted on polyvinylidene difluoride membrane were detected by incubation with primary antibodies overnight at $4^{\circ} \mathrm{C}$. In the case of primary monoclonal antibodies, the blots were incubated with a second rabbit anti-species antibody for $1 \mathrm{hr}$ at room temperature. Bound antibodies were detected with ${ }^{125} \mathrm{I}$-labeled protein $\mathrm{A}(0.12 \mu \mathrm{Ci} / \mathrm{ml}, 1 \mathrm{hr}$ incubation at room temperature). In radioactive metabolic experiments, incorporated radiolabel was visualized after the gels were dried and exposed to x-ray film (Hyperfilm MP, Amersham-Buchler).

Biochemical studies on the AN2 antigen. For steady-state radiolabeling of the cell line Oli-neu, cells were incubated overnight with $100 \mu \mathrm{Ci} / \mathrm{ml}$ $\mathrm{L}-\left({ }^{35} \mathrm{~S}\right)$ in vitro labeling mix consisting of $70 \%$ methionine and $30 \%$ cysteine or $100 \mu \mathrm{Ci} / \mathrm{ml}{ }^{35} \mathrm{SO}_{4}$ (Amersham-Buchler). Subsequently an immunoprecipitation was performed [basically as described in Faissner et al. (1985)], using the monoclonal AN2 antibody and Protein-A Sepharose, which had been preincubated with rabbit anti-rat "bridge" antibody before addition to the cell lysate. For "pulse-chase" labeling, the cells were first incubated for $1 \mathrm{hr}$ in methionine/cysteine-free minimal essential medium (MEM) with $2 \mathrm{~mm}$ glutamine. The cells were then labeled for $5 \mathrm{~min}$ with $300 \mu \mathrm{Ci} / \mathrm{ml} \mathrm{L}-\left({ }^{35} \mathrm{~S}\right)$ in vitro labeling mix and subsequently incubated for various lengths of time in Sato/ $1 \% \mathrm{HS}, 5 \mathrm{~mm}$ methionine, and $5 \mathrm{~mm}$ cysteine ("chase" medium), followed by immunoprecipitation.

To analyze the intermediate stages of glycosylation, $5 \mathrm{mg} / \mathrm{ml}$ tunicamycin or $5 \mathrm{~mm}$ swainsonine was added to the medium for the last $15 \mathrm{~min}$ of incubation in methionine/cysteine-free medium before the addition of radioactivity. $\mathrm{L}-\left({ }^{35} \mathrm{~S}\right)$ in vitro labeling $\operatorname{mix}(200 \mu \mathrm{Ci} / \mathrm{ml})$ was then added, and the cells were incubated further for $1 \mathrm{hr}$, followed by a $15 \mathrm{~min}$ incubation in chase medium in the presence of $5 \mathrm{mg} / \mathrm{ml}$ tunicamycin (Elbein, 1981) or $5 \mathrm{~mm}$ swainsonine, and subsequent immunoprecipitation.

Enzymatic digestion of carbohydrate epitopes and chondroitin sulfate residues. Affinity-purified antigen $(10 \mu \mathrm{g})$ was freeze-dried, taken up in $20 \mu 11 \%$ SDS, and heated at $100^{\circ} \mathrm{C}$ for $2 \mathrm{~min}$. Subsequently, $180 \mu 120$ mm Na-phosphate, pH 7.2, $10 \mathrm{~mm}$ Na-azide, $50 \mathrm{~mm}$ EDTA, and 0.5\% 
B
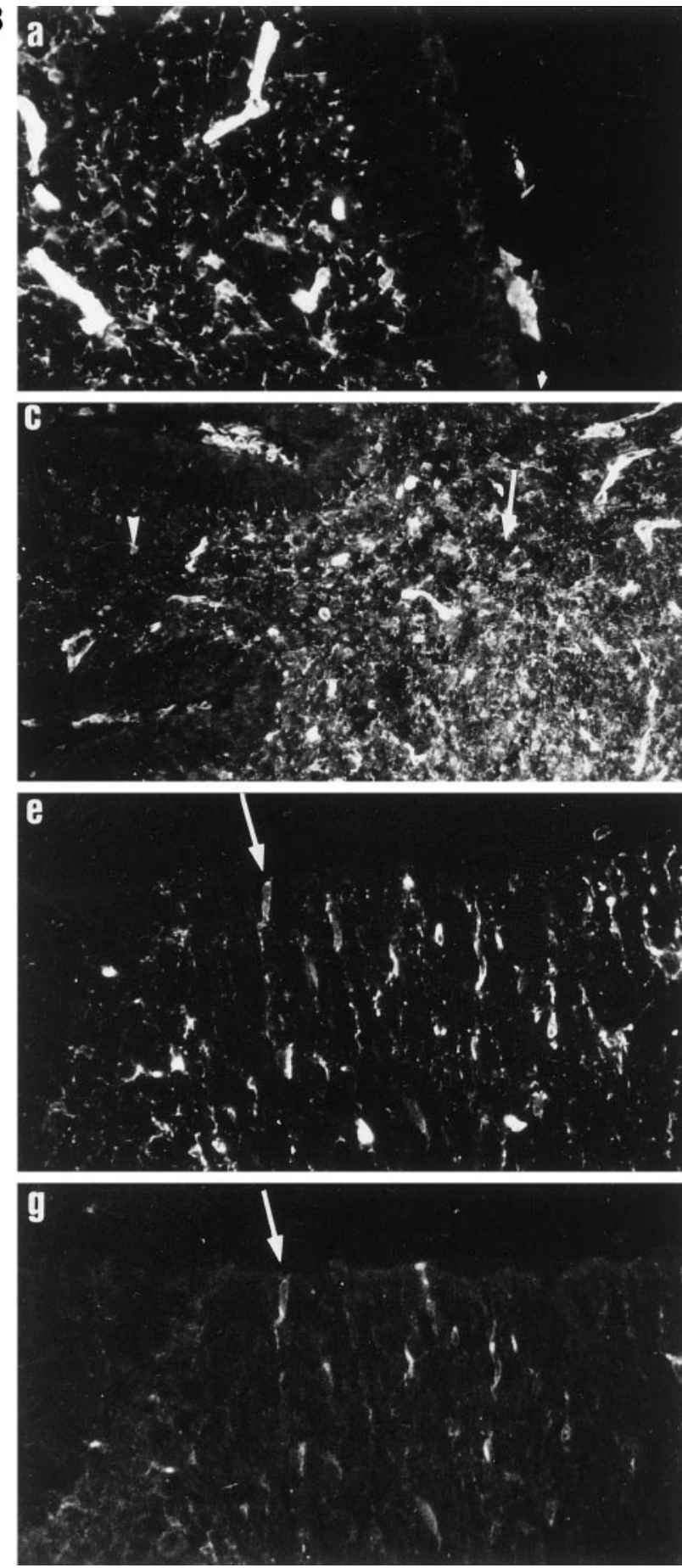
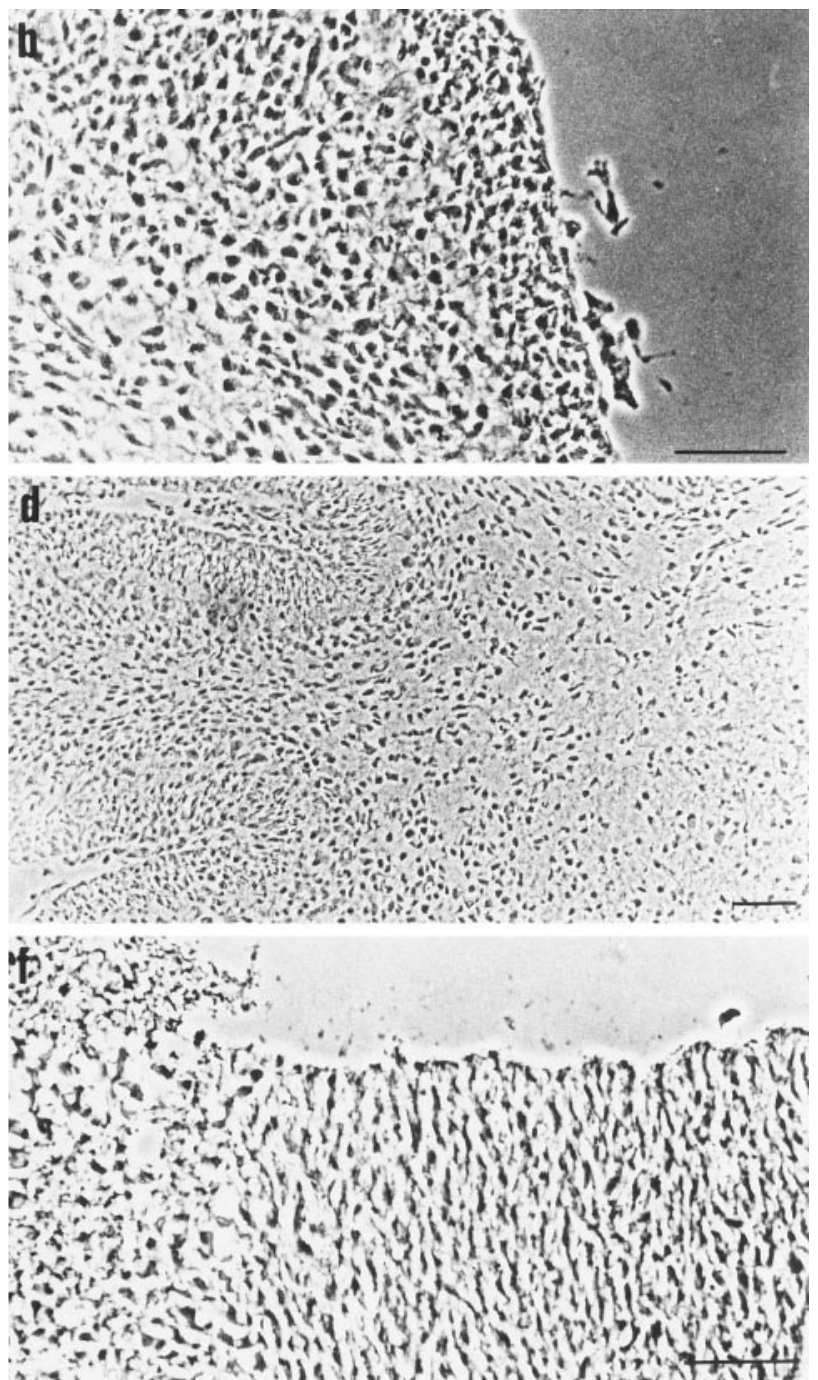

Figure 1. B, Staining of brain sections with the AN2 antibody. Shown is immunohistochemical staining of cryosections: $a, \mathrm{P} 7$ cerebellum stained with AN2; $c$, overview of P6 cerebellum stained with AN2 antibody. Note the higher density of stained cells at the base of the cerebellum (arrow) compared with the more distal part (arrowhead); $e, \mathrm{P} 6$ forebrain stained with AN2; and $g$, PDGF- $\alpha$-receptor. An example of a double-labeled cell is indicated by an arrow. Corresponding phase-contrast pictures are in $b$, $d$, and $f$. Scale bar, $50 \mu \mathrm{m}$.
NP-40 was added, and the mixture was heated again for 2 min at $100^{\circ} \mathrm{C}$. After cooling, either $0.4 \mathrm{U} N$-glycosidase F, $2.5 \mathrm{mU} O$-glycosidase, or 2 $\mathrm{mU}$ neuraminidase was added and incubated for $19 \mathrm{hr}$ at $37^{\circ} \mathrm{C}$.

Immunoprecipitated protein was subjected to digestion with chondroitinase ABC from Proteus vulgaris. The Protein A-Sepharose-bound protein was dissolved in $100 \mu \mathrm{l}$ buffer $(50 \mathrm{~mm}$ Tris/ $\mathrm{HCl}, \mathrm{pH} 8,50 \mathrm{~mm}$ Na-acetate, $100 \mathrm{mg} / \mathrm{ml} \mathrm{BSA,} 10 \mathrm{mg} / \mathrm{ml}$ ovomucoid, and $1 \mathrm{~mm}$ PMSF), 180 $\mathrm{mU} / \mathrm{ml}$ enzyme was added, and the mixture was incubated at $37^{\circ} \mathrm{C}$ for 3 $\mathrm{hr}$. The reactions in each case were stopped by addition of sample buffer, and analysis was performed by gel electrophoresis.

Inhibition of neural cell attachment test. The inhibition of neural cell attachment test was performed as described in Faissner and Kruse (1990). In brief, glass coverslips were coated with poly-L-ornithine (PORN), which was allowed to dry. The affinity-purified AN2 antigen
$(10-20 \mu \mathrm{g} / \mathrm{ml})$ was then coated on top of the PORN substrate. A pattern was then scratched in the AN2 substrate using a yellow Eppendorf tip, leaving AN2-coated and AN2-free (PORN only) areas of the coverslip. The stripes could be visualized by immunofluorescent staining with the AN2 monoclonal antibody. Different cell populations were then added to the coverslips and flooded with medium after $5 \mathrm{hr}$ of culture. After 24 and $48 \mathrm{hr}$, the distribution of the cells on the coverslips was examined. In some cases, the cells were visualized by staining the coverslips with Toluidine blue (see below); in other cases the coverslips were stained with cell type-specific markers.

Migration assay. We established migration assays using modifications of the technique described by Amberger et al. (1997) using CG4 cells and primary "oligospheres" (Avellana-Adalid et al., 1996). Aggregate cultures of the Oli-neu cell line were generated by suspending the cells at 

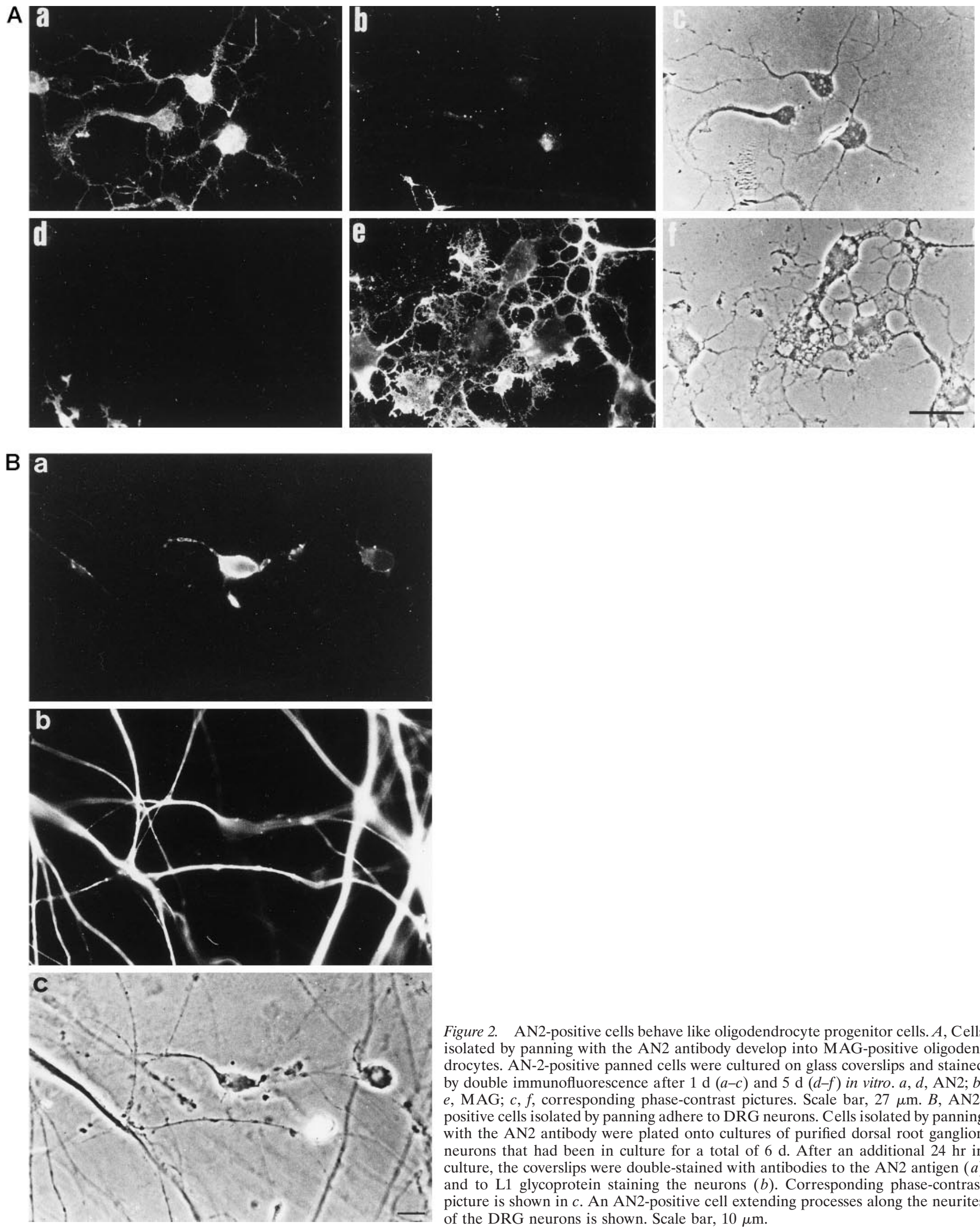

Figure 2. AN2-positive cells behave like oligodendrocyte progenitor cells. $A$, Cells isolated by panning with the AN2 antibody develop into MAG-positive oligodendrocytes. AN-2-positive panned cells were cultured on glass coverslips and stained by double immunofluorescence after $1 \mathrm{~d}(a-c)$ and $5 \mathrm{~d}(d-f)$ in vitro. $a, d, \mathrm{AN} 2 ; b$, $e$, MAG; $c$, $f$, corresponding phase-contrast pictures. Scale bar, $27 \mu \mathrm{m}$. B, AN2positive cells isolated by panning adhere to DRG neurons. Cells isolated by panning with the AN2 antibody were plated onto cultures of purified dorsal root ganglion neurons that had been in culture for a total of $6 \mathrm{~d}$. After an additional $24 \mathrm{hr}$ in culture, the coverslips were double-stained with antibodies to the AN2 antigen $(a)$ and to L1 glycoprotein staining the neurons $(b)$. Corresponding phase-contrast picture is shown in $c$. An AN2-positive cell extending processes along the neurites of the DRG neurons is shown. Scale bar, $10 \mu \mathrm{m}$. 
$1 \times 10^{6}$ cells $/ \mathrm{ml}$ in Sato/1\% HS in glass flasks rotating at $70 \mathrm{rpm}$. After $24 \mathrm{hr}$, the aggregates were plated on coverslips coated with different substrates. Medium, in some cases including antibody, was added after the aggregates had settled (after $2 \mathrm{hr}$ ). After different times in culture, the cells were fixed by incubation in $2.5 \%$ glutaraldehyde for $1 \mathrm{hr}$, followed by washing with PBS and incubation in $0.5 \%$ Toluidine blue in $2.5 \%$ sodium carbonate for $15 \mathrm{~min}$, washed, and coverslipped. The distance the cells had migrated out from the central aggregate core was measured using the Leica Quantimate 500 software (Leica, Bensheim, Germany) in combination with an inverted microscope and attached camera. The area covered by the aggregate and the area covered by the aggregate plus migrating cells were measured. Assuming that both were circles, the migration distance was determined by subtraction of these two radii.

Shaken-off oligodendrocytes and progenitors were suspended in Sato/1\% HS plus $5 \mathrm{ng} / \mathrm{ml}$ basic FGF (bFGF) and $10 \mathrm{ng} / \mathrm{ml} \mathrm{PDGF}$ at a concentration of $3.5 \times 10^{6}$ cells $/ 4 \mathrm{ml}$ in a glass flask and rotated at 70 $\mathrm{rpm}$. After $24 \mathrm{hr}$ the resulting aggregates were washed once with warm medium and seeded on PLL-coated coverslips lying in the wells of a 24-well plate. The aggregates were cultured in the above medium, and after they were allowed to adhere for $4 \mathrm{hr}$, additional culture medium was added. Additions of antibody and factors were made daily, and after $3 \mathrm{~d}$ the cells were fixed and stained with Toluidine blue or stained with cell type-specific antibodies. Because the aggregates from primary cells are not as even in shape as those generated with the Oli-neu cell line, the migration was determined as the ratio between the area covered by the aggregate and migrating cells and the area covered by the aggregate core.

Statistical analysis of data. All types of migration experiments (Oliпеи \pm monoclonal and polyclonal AN2 antibodies, primary cells \pm monoclonal and polyclonal AN2 antibodies, and Oli-neu \pm polyclonal F3 antibodies) were performed at least four times, yielding similar results. For each migration experiment with Oli-neu, 20 aggregates were measured for each data point distributed over four different wells. For the primary cells, 9-21 aggregates were measured for each data point dis-
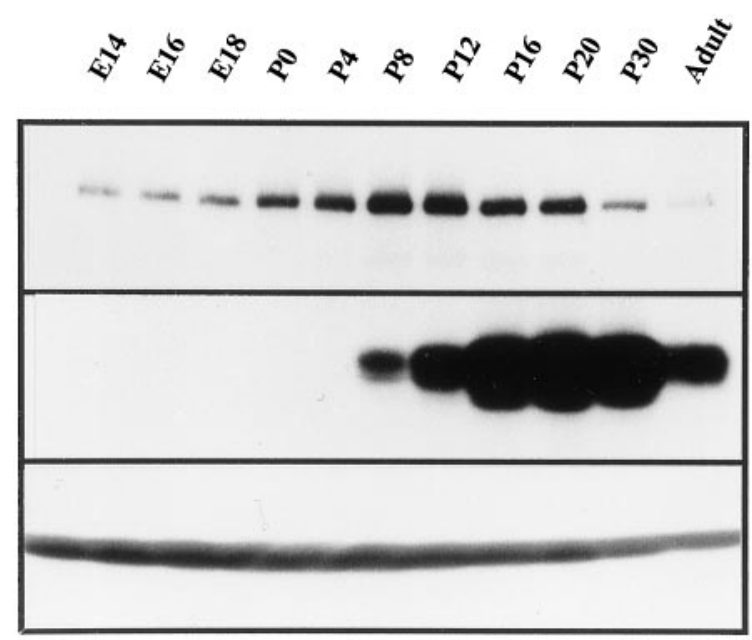

AN2

MAG

Figure 3. Developmental expression of the AN2 antigen in the CNS during mouse development. Equal amounts of protein $(150 \mu \mathrm{g} / \mathrm{lane})$ from mouse brain of different developmental stages were subjected to electrophoretic separation and Western blotting. The blot was then incubated with the AN2 monoclonal antibody (top panel), with polyclonal antibodies to MAG (middle panel), or with a monoclonal antibody to tubulin (bottom panel) and developed as described in the text. The same blot was stripped after development with the AN2 antibody and reprobed with the MAG and tubulin antibodies.
A

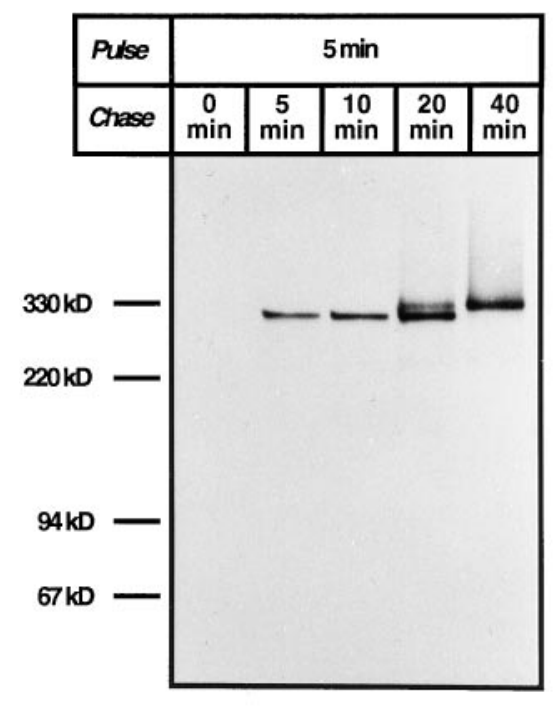

B

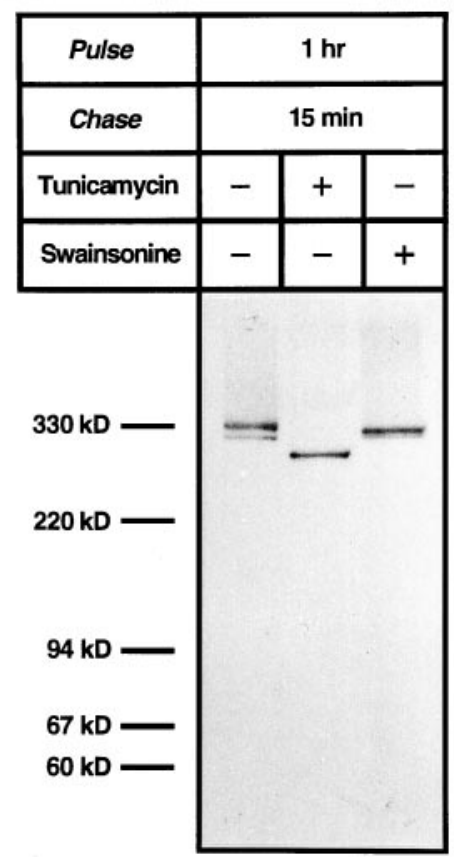

C

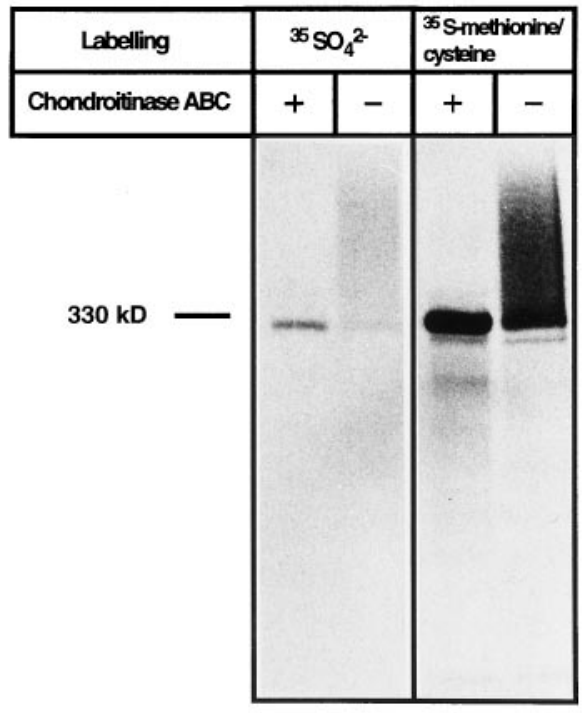

Figure 4. Biosynthesis of the AN2 antigen in the cell line Oli-neu.A, Pulse-chase radiolabeling. Oli-neu cells were incubated 5 min with ${ }^{35} \mathrm{~S}$-methionine/ cysteine followed by immunoprecipitation with the monoclonal AN2 antibody after different "chase" times. $B$, Immunoprecipitation from cells in the presence of inhibitors of glycosylation. Immunoprecipitation with the AN2 monoclonal antibody was performed on Oli-neu cells labeled with ${ }^{35} \mathrm{~S}$-methionine/cysteine. A change in the migration of the AN2 protein in the presence $(+)$ relative to the absence $(-)$ of tunicamycin (inhibits $\mathrm{N}$-glycosylation) or swainsonine (inhibits mannosidase II) shows that AN2 carries N-linked sugars. $C$, Immunoprecipitation from ${ }^{35} \mathrm{~S}$-sulfate-labeled cells. Immunoprecipitation with the AN2 monoclonal antibody was performed on Oli-neu cells labeled with ${ }^{35} \mathrm{~S}$-sulfate or ${ }^{35} \mathrm{~S}$-methionine/cysteine. Chondroitinase $\mathrm{ABC}$ treatment $(+)$ of the ${ }^{35} \mathrm{~S}$-sulfate immunoprecipitate converts the broad signal in the absence of enzyme treatment $(-)$ into a sharp band, demonstrating that the antigen carries GAG chains. Immunoprecipitation of ${ }^{35} \mathrm{~S}$-methionine/cysteine-labeled cells shows in addition to the smear a sharp band at $330 \mathrm{kDa}$, demonstrating that only a subpopulation of the protein carries GAG chains. Incubation of the immunoprecipitate with chondroitinase $\mathrm{ABC}(+)$ results in the disappearance of the smear and a stronger signal at $330 \mathrm{kDa}$. 
A

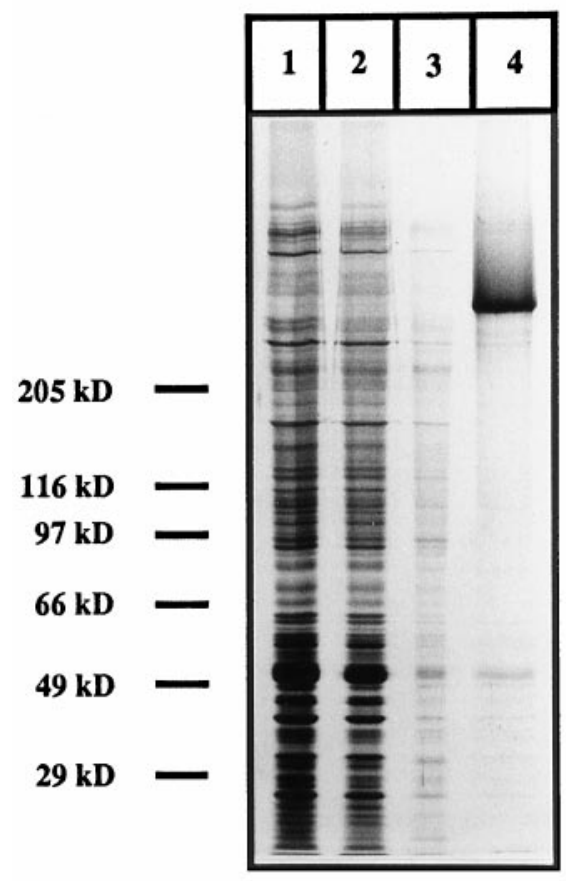

B

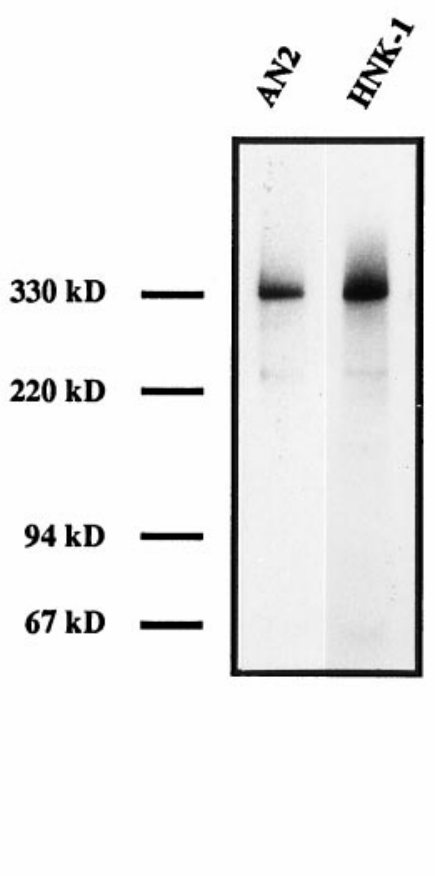

C

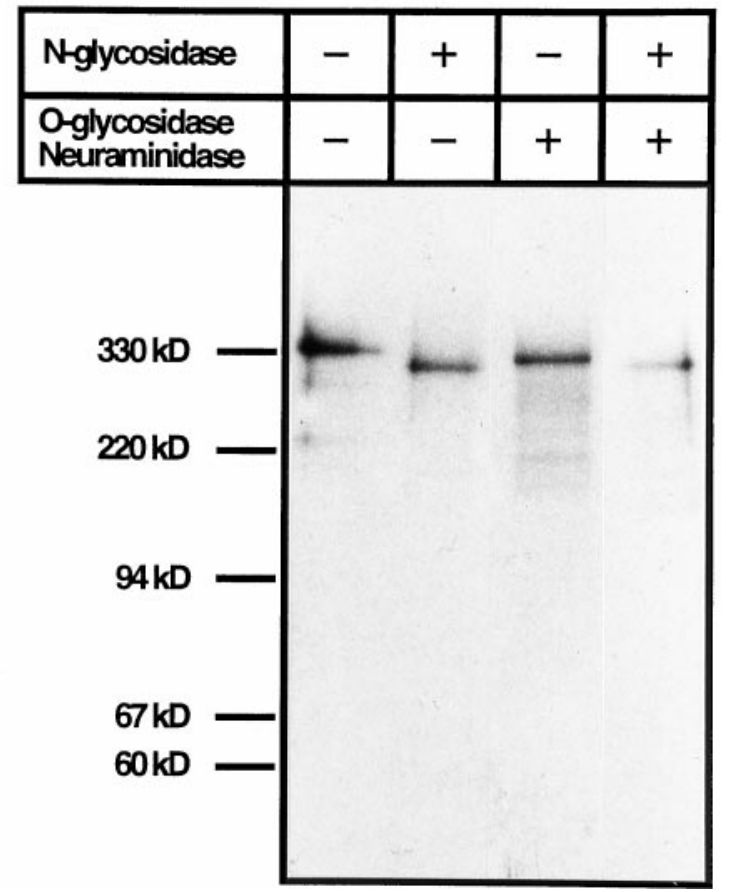

Figure 5. Characterization of the AN2 antigen isolated by immunoaffinity chromatography. $A$, Isolation of the antigen was as follows: $1 \mu$ l of each of the homogenate (lane 1), the post-nuclear supernatant (lane 2), the membrane preparation after the pH 11 strip (lane 3 ), and $60 \mu \mathrm{l}$ from a total of $3 \mathrm{ml}$ of the concentrated eluate from the AN2 affinity column (lane 4) were separated by gel electrophoresis and visualized by silver staining of the gel. $B$, The AN2 antigen expresses the HNK-1 carbohydrate epitope. The antigen preparation $(0.4 \mu \mathrm{g})$ was separated by electrophoresis and analyzed by Western blotting using the AN2 monoclonal antibody or the 412 monoclonal antibody recognizing the HNK-1 carbohydrate epitope. $C$. Digestion with $N$-glycosidase F or $O$-glycosidase and neuraminidase affects the molecular size of the AN2 antigen. The antigen preparation $(10 \mu \mathrm{g})$ was incubated for $19 \mathrm{hr}$ at $37^{\circ} \mathrm{C}$ with $0.4 \mathrm{U} \mathrm{N}$-glycosidase F or $2.5 \mathrm{mU} O$-glycosidase and $2 \mathrm{mU}$ neuraminidase, subjected to gel electrophoresis, and analyzed by Western blotting with the AN2 monoclonal antibody. The migration of the AN2 band shifts in the presence of the enzymes, showing that the antigen carries N-linked (and possibly some O-linked) sugars, and that the monoclonal antibody recognizes the core protein of the antigen.

\begin{tabular}{|c|c|c|c|c|}
\hline Fraction & $\begin{array}{l}\text { Protein } \\
\text { concentration }\end{array}$ & Volume & $\begin{array}{l}\text { Amount of } \\
\text { protein }\end{array}$ & $\begin{array}{l}\text { Purification } \\
\text { factor }\end{array}$ \\
\hline Homogenate & $24.8 \mathrm{mg} / \mathrm{ml}$ & $120 \mathrm{ml}$ & $3.0 \mathrm{~g}$ & 1 \\
\hline Membrane preparation & $11.2 \mathrm{mg} / \mathrm{ml}$ & $120 \mathrm{ml}$ & $1.3 \mathrm{~g}$ & 2.3 \\
\hline Post-nuclear fraction & $2.6 \mathrm{mg} / \mathrm{ml}$ & $120 \mathrm{ml}$ & $0.3 \mathrm{~g}$ & 10 \\
\hline Eluate & $80 \mu \mathrm{g} / \mathrm{ml}$ & $3 \mathrm{ml}$ & $240 \mu \mathrm{g}$ & 12,500 \\
\hline
\end{tabular}

The table shows the amount of total protein in the different fractions and hence the purification factor. The starting material was $20 \mathrm{~g}$ of P9 mouse brain.

tributed over three wells. For the time course experiment, 40 aggregates were measured for each point on the graph. Because it cannot be assumed that the migration follows a Gaussian distribution, to analyze the significance of the observed differences the nonparametric test ANOVA on ranks followed by Dunn's test was applied.

\section{RESULTS}

\section{The AN2 antigen is expressed by oligodendrocyte precursor cells but not by mature oligodendrocytes, astrocytes, or neurons}

The AN2 monoclonal antibody stains the surface of unfixed oligodendrocyte progenitor cells in cultures established from embryonic day 14 mouse brain. After $10 \mathrm{~d}$ these cultures contain astrocytes, neurons, and oligodendrocytes as well as a range of progenitor cell types (Fig. $1 A$ ). AN2 expression partially overlaps with that of $\mathrm{O} 4$ and LB1 antigens and stains cells of simple morphology (Fig. $1 A, a-c, d-f$ ) but does not overlap with markers for more differentiated oligodendrocytes such as O1, proteolipid protein (PLP), or MAG (data not shown). The fine filopodia emanating from the tips of the processes are especially strongly stained for AN2; this is more evident in color photos (data not shown). No overlap with either GFAP (Fig. $1 A, g-i$ ) or L1 (Fig. $1 A, j-l)$, markers of astrocytes or neurons, was seen. No staining of fibronectin-positive fibroblasts was observed (data not shown). Staining of shaken-off murine oligodendrocytes (Trotter et al., 1989) and cultures from P6 murine cerebella yielded a similar result with AN2 staining partially overlapping with $\mathrm{O} 4$ and LB1 staining (data not shown).

The expression of the AN2 antigen was also analyzed in tissue sections (Fig. $1 B$ ). On cryosections of early postnatal cerebellum (Fig. $1 B, a, b)$, the antibody stained cells with small cell bodies and several fine processes. In addition, the large stained structures in Figure $1 B, a$, are developing capillaries, some of which appear 
A
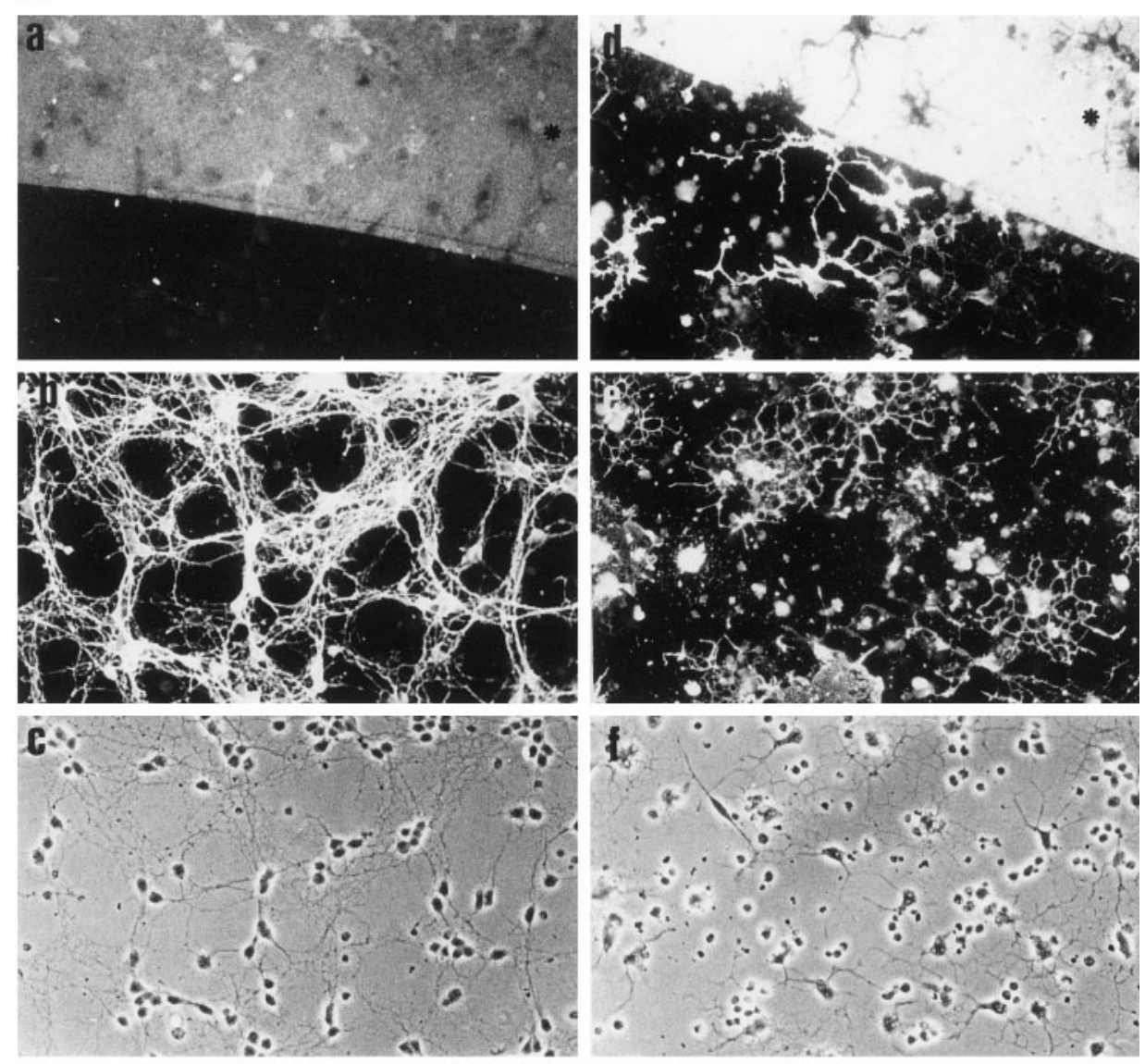

B
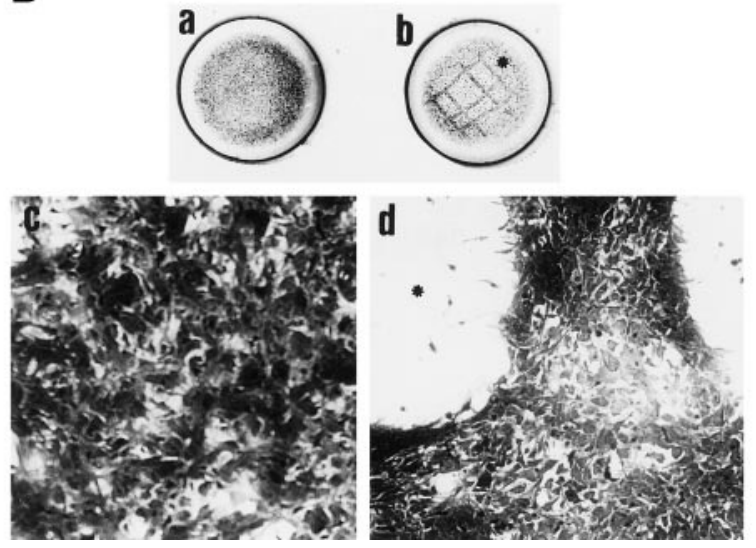

Figure 6. The behavior of oligodendrocytes, cerebellar granule cells, and astrocytes on AN2 antigen and PORN substrates. $A$, Cerebellar neurons and oligodendrocytes grow equally well on AN2 and PORN. Cells were cultured on patterned substrates consisting of areas coated with PORN alone and areas with AN2 over PORN. Coverslips were doublestained with $\mathrm{AN} 2(a)$ and $\mathrm{L} 1(b)$ or $\mathrm{AN} 2(d)$ and $\mathrm{O} 4(e) . c, f$, Corresponding phase-contrast pictures. The AN2-coated area is indicated with an asterisk. Cerebellar neurons and oligodendrocytes attach equally well to the two different substrates and extend processes (oligodendrocytes) or extend long neurites (granule cell neurons). $B$, Astrocytes prefer a PORN substrate to the AN2 substrate. Astrocytes cultured on coverslips coated with PORN alone after $24 \mathrm{hr}(a)$ or after $48 \mathrm{hr}(c)$ are shown. Astrocytes cultured on a patterned substrate with stripes of PORN and areas coated with AN2 are shown after $24 \mathrm{hr}(b)$ or $48 \mathrm{hr}(d)$ in culture. The asterisks in $b$ and $d$ indicate areas coated with AN2. As can be seen from the grid-like pattern in $b$ and $d$, the astrocytes grow well on the PORN, whereas the AN2 substrate is unfavorable for long-term growth of astrocytes. positive. Cells were located mainly in the forming white matter tracts but also in the granular cell layer and Purkinje cell layer between the white matter tracts and the molecular layer. No staining of the molecular layer or of the Bergmann glia was observed. The stained cells appear in a gradient with more cells at the base of the cerebellum (arrow) than at the distal part of the foci (Fig. 1B, c, d, arrowheads). Double stainings of P6 forebrain showed that some, but not all, AN2-positive cells also expressed PDGF- $\alpha$-receptor, a marker for oligodendrocyte progenitor cells (Fig. 1B,e,g) (Pringle and Richardson, 1993; Hall et al., 1996). There was no overlap with GFAP, $\beta$-III tubulin (for young neurons), MAP-2, or MAG, or with F4/80 or MAC-1 as markers for microglia (data not shown). On sections of adult brain, stained cells in both white and gray matter are seen, but no capillaries are stained (data not shown).

\section{The AN2 antigen-positive cells differentiate into mature oligodendrocytes in vitro}

The above observations strongly suggest that the antibody stains oligodendrocyte progenitor cells. To confirm that the AN2positive cells can differentiate into oligodendrocytes in vitro, the AN2-positive cells were isolated by panning from shaken-off oligodendrocytes and precursors and cultured on coverslips. The cells were analyzed for expression of AN2 and MAG, O4, O1, or GFAP after different times in vitro. Because the trypsinization used to release the selected cells from the panning dish also 


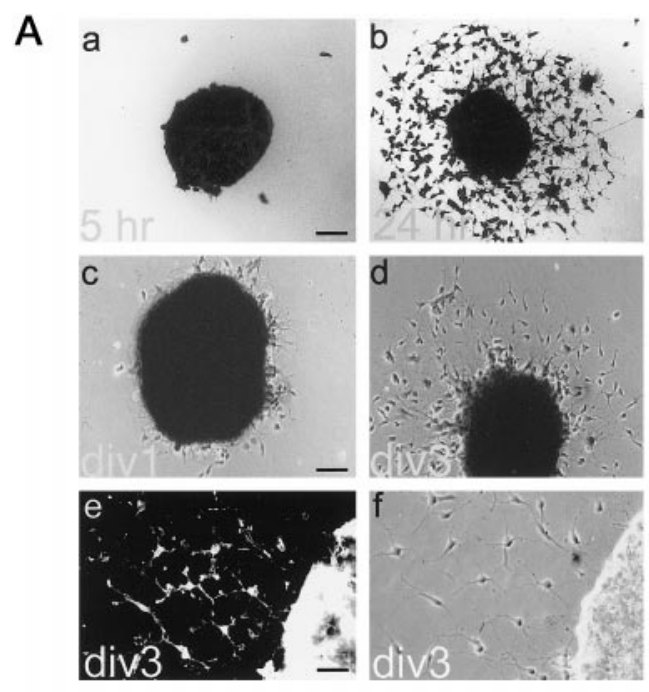

B

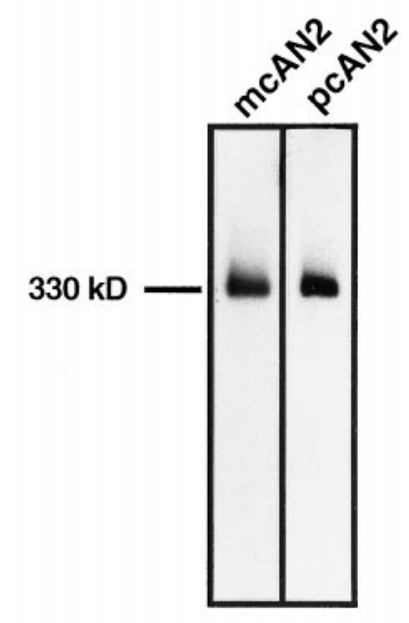

C
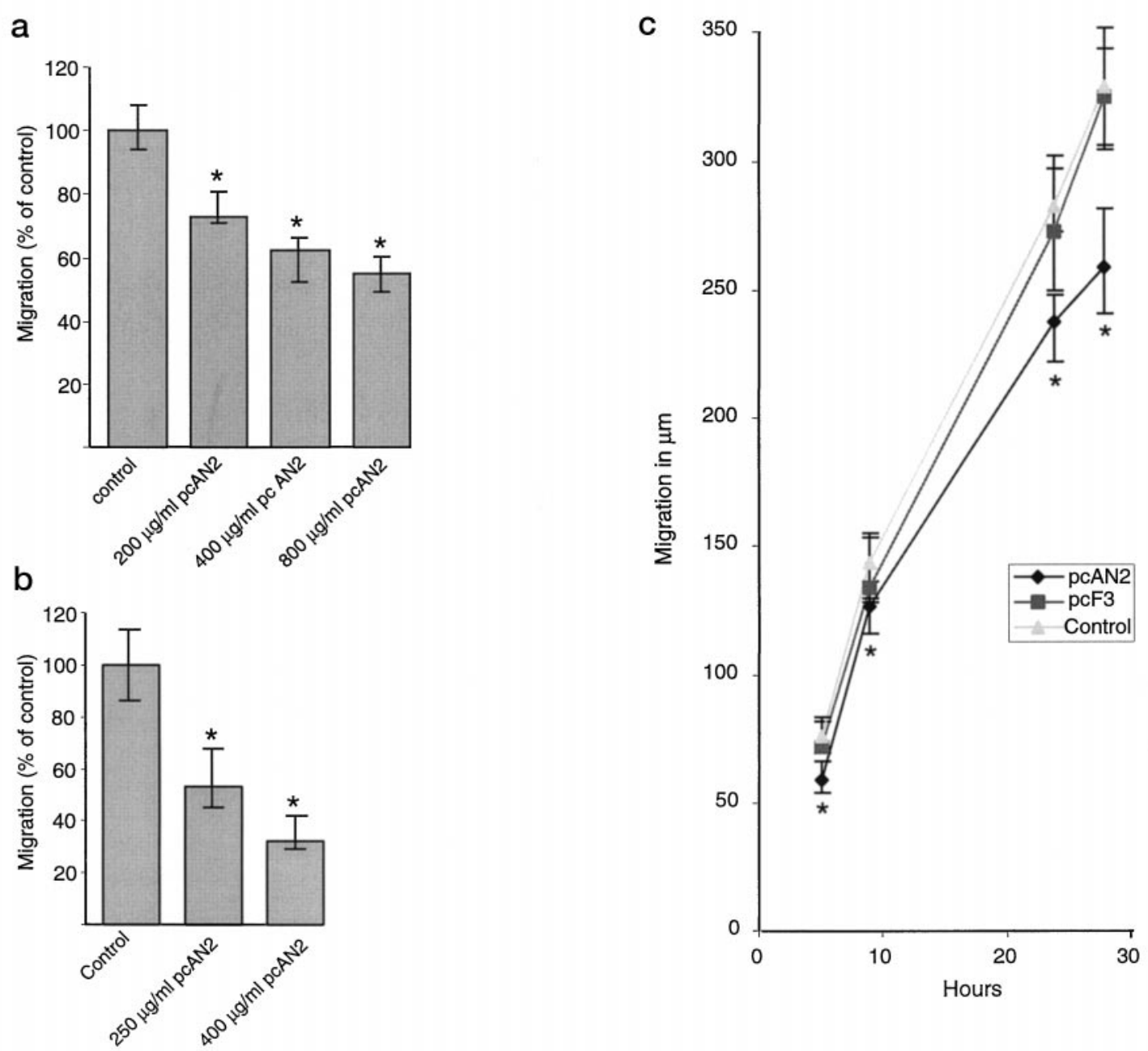

Figure 7. The AN2 antigen is involved in the migration of oligodendrocyte progenitor cells. A, Migration from aggregates of Oli-neu cells or primary oligodendrocytes. Aggregates of Oli-neu cells or primary oligodendrocyte lineage cells were plated on poly-L-lysine-coated glass coverslips. $a$ shows an Oli-neu aggregate $5 \mathrm{hr}$ after plating; $b$ shows an Oli-neu aggregate $24 \mathrm{hr}$ after plating; $c$ shows an aggregate of primary cells $1 \mathrm{~d}$ after plating; $d$ shows an aggregate of primary cells $3 \mathrm{~d}$ after plating; $e$ shows staining of the cells migrating from aggregates of primary cells with the AN2 monoclonal antibody; and $f$ shows corresponding phase-contrast picture. div, Days in vitro. Scale bars: $a-d, 60 \mu \mathrm{m} ; e, f, 30 \mu \mathrm{m}$. $B$, Western blot to demonstrate the specificity of the AN2 polyclonal antibodies that were used. Proteins of whole mouse brain (P9) were separated by SDS-PAGE and blotted onto nitrocellulose. The blots were probed with either the monoclonal AN2 antibody (left lane) or polyclonal AN2 antibodies (right lane). The polyclonal and monoclonal antibodies show a similar specificity. C, AN2 polyclonal antibodies reduce the migration of Oli-neu or primary (Figure legend continues) 
removes the AN2 antigen, immediately after isolation the panned cells were AN2 negative (data not shown). However, after $4 \mathrm{hr}$ of culture, all of the selected cells were weakly AN2 positive, confirming the specificity of the panning, and $>95 \%$ were still AN2 positive after $1 \mathrm{~d}$ in culture (Fig. $2 A, a$ ). These cells were MAGnegative (Fig. $2 A, b$ ). After $2 \mathrm{~d}$ in culture, $\sim 30 \%$ of the cells expressed MAG and were AN2 negative. After $5 \mathrm{~d}$ in culture, no cells were seen staining with the AN2 antibody (Fig. $2 A, d$ ), and $>98 \%$ of the cells now expressed MAG (Fig. $2 A, e$ ). The antigens $\mathrm{O} 4$ and $\mathrm{O} 1$ appeared earlier than $\mathrm{MAG}$, and some overlap of O4 and AN2 but not of $\mathrm{O} 1$ and AN2 staining was seen (data not shown). These experiments thus demonstrate that AN2-positive cells differentiated into oligodendrocytes. This result was seen in three independent experiments. When the isolated AN2-positive cells were added to cultures of dorsal root ganglion neurons, they attached on or very near neurites, and all extended processes along the neurites in a manner typical of oligodendrocyte progenitor cells (Fig. 2B). This result was observed in three independent experiments (observation of several hundred cells).

\section{The antibody recognizes a glycoprotein of $330 \mathrm{kDa}$ with a peak of expression during myelination}

Western blots of total mouse brain of different developmental stages (E14 to adult) showed that the antibody recognizes a protein of $330 \mathrm{kDa}$ (Fig. 3). The expression of the antigen peaked at P8-P12, coinciding with myelination, and was strongly downregulated in adult brain. In contrast, the expression of the MAG, which is upregulated during differentiation of precursor cells to oligodendrocytes and also expressed in myelin, started later and was a dominant signal in the adult brain. Interestingly, expression of the AN2 protein in the Western blot is already visible at E14. The similar expression of $\alpha$-tubulin in each lane confirmed that equal amounts of total protein were applied. Western blots of cultures of oligodendrocytes or the cell line Oli-neu also showed that the AN2 antibody recognizes a protein of $330 \mathrm{kDa}$ (data not shown).

\section{Biochemical characterization of the protein}

Pulse-chase experiments of the cell line Oli-neu using the monoclonal AN2 antibody (Fig. $4 A$ ) showed that the mature protein of $330 \mathrm{kDa}$ is synthesized from a precursor of $315 \mathrm{kDa}$. After $20 \mathrm{~min}$ of chase, the mature form of the protein is seen together with the immature form, and after $40 \mathrm{~min}$ only the mature form is seen. Immunoprecipitation from Oli-neu cells radiolabeled in the presence of tunicamycin, which inhibits $\mathrm{N}$-glycosylation, resulted in the precipitation of a $290 \mathrm{kDa}$ form of the protein and shows that the AN2 antigen carries $10-15 \%$ of the molecular mass as $\mathrm{N}$-glycosylated carbohydrates (Fig. $4 B$ ). In the presence of swainsonine, which inhibits mannosidase II, a $320 \mathrm{kDa}$ partially glycosylated form of the protein was precipitated. When metabolic labeling of Oli-neu was performed in the presence of ${ }^{35} \mathrm{~S}$-sulfate, immunoprecipitation with the AN2 antibody showed a smear of higher molecular mass in addition to a weak $330 \mathrm{kDa}$ band (Fig. $4 C$ ). Digestion with chondroitinase $\mathrm{ABC}$ resulted in a loss of the smear and the resolution of a single band of $330 \mathrm{kDa}$. This experiment demonstrated that the AN2 antigen carries a limited number of glycosaminoglycan (GAG) chains. That only a subpopulation of the antigen carries GAG chains is also suggested by immunoprecipitations from ${ }^{35} \mathrm{~S}$-methionine/cysteine-labeled cells in which a sharp protein band at $330 \mathrm{kDa}$ is observed in addition to a weak smear of higher molecular mass. After incubation of the immunoprecipitate with chondroitinase $\mathrm{ABC}$, this smear disappears, and the intensity of the $330 \mathrm{kDa}$ band increases (Fig. 4C).

Immunoaffinity isolation of the AN2 protein was performed from early postnatal mouse brain. The successive steps of the purification can be seen in Figure $5 A$. The isolated protein has a molecular mass of $330 \mathrm{kDa}$ as seen by silver staining of the final preparation (lane 4). To characterize the purification quantitatively, the protein content of the different steps of the preparation was measured (Table 1). Thus, the purification factor for the final antigen preparation could be estimated. Western blotting of this preparation showed that the isolated antigen expresses the HNK-1 carbohydrate epitope (Fig. 5B). Digestion of the purified antigen with $N$-glycosidase F (Fig. $5 C$ ) resulted in a reduction of the molecular mass by $\sim 30 \mathrm{kDa}$, supporting the results of the immunoprecipitation in the presence of tunicamycin. Digestion with $O$-glycosidase and neuraminidase resulted in a very small decrease in molecular mass $(\sim 15 \mathrm{kDa})$, whereas in the presence of all three enzymes the digested protein had a molecular mass of $300 \mathrm{kDa}$ (Fig. 5C). These experiments also suggest that the monoclonal antibody recognizes the protein core of the antigen.

\section{The protein is adhesive for oligodendrocytes and cerebellar neurons but after initial adhesion astrocytes do not grow on the AN2 antigen}

The attachment and growth of different cells on the AN2 substrate and the AN2-free (PORN) area of patterned coverslips were analyzed. Granule neurons from P6 cerebella were plated onto the patterned substrates, and after $48 \mathrm{hr}$ in vitro a dense network of L1-positive neurites covering the surface was visible (Fig. 6A, $b$ ). No distinction could be made between AN2-coated and AN2-free areas of the coverslip. Neurites and cell bodies were located on AN2-coated as well as AN2-free areas of the glass. Oligodendrocyte primary cultures behaved similarly: O4positive cells could be seen growing on both the AN2 substrate and the AN2-free areas of the coverslip (Fig. 6 A,e). The cell line Oli-neu also made no distinction between the two different substrates (data not shown). In contrast, cultures of cortical astrocytes initially adhered to both substrates, but after $24 \mathrm{hr}$ on the patterned coverslips, a grid-like pattern was seen, with the cells growing more densely on the AN2-free areas of substrate (Fig. $6 B, b)$ in contrast to PORN alone, where the cells grew evenly distributed (Fig. 6B, a). After $48 \mathrm{hr}$ this pattern was even clearer,

\section{$\longleftarrow$}

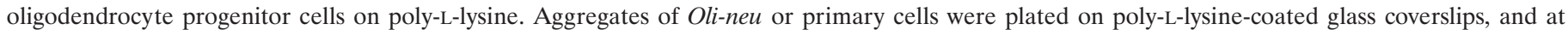

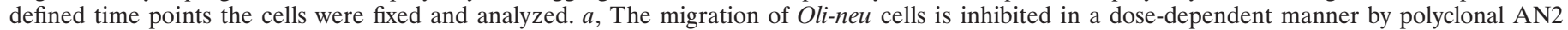

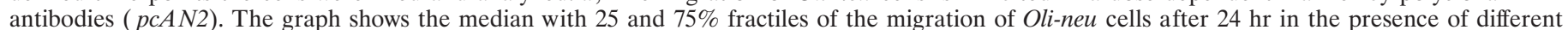

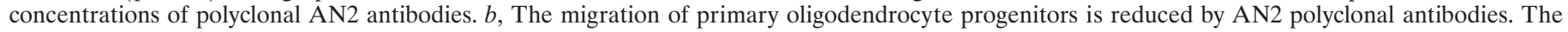

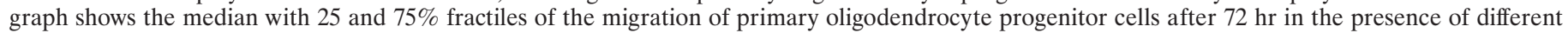

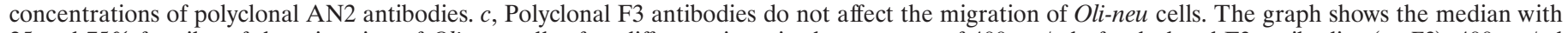

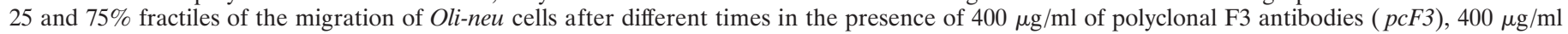

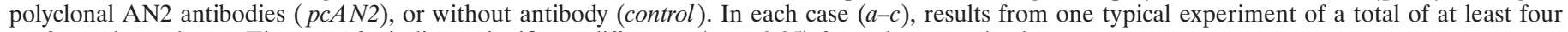
performed are shown. The asterisks indicate significant difference $(p<0.05)$ from the control value. 
and the AN2-positive areas of the coverslip were now largely free of cells (Fig. $6 B, d$ ). Interestingly, the few remaining cells growing on the AN2 substrate areas were microglia or oligodendrocyte progenitor cells that were contaminants in the astrocyte population. When the AN2 substrate was mixed with laminin, the repulsive effect on astrocytes was abolished (data not shown). Short-term adhesion assays showed that oligodendrocytes (primary cultures and cell line) as well as astrocytes adhere to the AN2 protein when tested after $2 \mathrm{hr}$ (data not shown). The grid pattern of astrocyte growth was eliminated after exposure of the coated coverslips to UV light, and the repulsive effect for astrocytes was unaffected by previous treatment of the antigen with chondroitinase $\mathrm{ABC}$, removing the GAG chains (data not shown).

\section{The AN2 protein is involved in the migration of oligodendrocyte precursor cells}

The AN2 antigen is expressed by oligodendrocyte progenitors that are migratory cells. To analyze a role of the protein in cell migration, we measured migration from aggregates of both the Oli-neu cell line (Fig. 7A, $a, b$ ) and primary oligodendrocytelineage cells (Fig. $7 A, c, d$ ). In the Oli-neu cell line, all cells express the AN2 antigen. The primary cells comprise a mixture of different stages of the lineage. However, when plated on adherent substrates, the aggregates attach, the mature stages of the lineage remain in the central core of the aggregate or very close to the edge, and the progenitor cells migrate out from the core of the aggregate. Greater than $95 \%$ of these emigrating cells are AN2 positive (Fig. $7 A, e, f$ ). Different substrates yielded a different rate of spreading of the circular migration front from the aggregate core of both Oli-neu and primary cells. The cells migrated fastest on laminin and less fast on pLL; they also migrated on an astrocyte extracellular matrix remaining after lysis of the cells with water (data not shown).

The migration assays were performed in the presence of polyclonal IgG AN2 antibodies. These antibodies show a similar pattern of reactivity to the monoclonal anti-rat IgG AN2 antibody on Western blots of total mouse brain (Fig. 7B) and in immunofluorescence staining of brain sections and cultured cells (data not shown). Polyclonal AN2 antibodies caused a reduction of the migration of both $\mathrm{Oli}$-neu and primary progenitor cells. The effect was maximal at a concentration of $\sim 400 \mu \mathrm{g} / \mathrm{ml}$, with a reduction of the migration to $50-60 \%$ of control values (Fig. $7 C, a, b$ ). In contrast, the monoclonal AN2 antibody had no effect on the migration. Addition of polyclonal antibodies against the F3 glycoprotein, which is expressed by oligodendrocyte progenitor cells and mature oligodendrocytes (Einheber et al., 1997; Koch et al., 1997), did not influence the migration (Fig. 7C, c). Analysis of the migration after different times showed that the addition of polyclonal AN2 antibodies resulted in a reduction in the rate of migration rather than a delayed exit from the explant (Fig. $7 C, c$ ). The antibody-induced reduction of migration was seen on a range of different substrates: poly-L-lysine, laminin, and fibronectin, but also astrocyte ECM, a more physiological substrate over which the cells probably migrate in vivo (Fok-Seang et al., 1995; Milner et al., 1996) (data not shown).

\section{DISCUSSION}

The AN2 antibody recognizes oligodendrocyte progenitor cells in the early postnatal CNS

The AN2 antigen is expressed by immature oligodendroglial progenitor cells in vitro and in vivo but not by cells expressing markers of mature oligodendrocytes, astrocytes, neurons, or mi- croglia. A partial overlap of AN2 expression and the markers O4 and LB1 in culture supports this view. Staining of sections of early postnatal murine cerebellum showed AN2-positive cells distributed similarly to GD3-positive precursor cells in the rat studied by Reynolds and Wilkin (1988). The ganglioside GD3 is expressed by oligodendrocyte progenitor cells but is not exclusive to these cells (Cammer and Zhang, 1996). In P6 forebrain, we observed AN2-positive cells that expressed the PDGF $\alpha$ receptor, an accepted marker for oligodendroglial progenitor cells (Pringle et al., 1992; Pringle and Richardson, 1993; Hall et al., 1996), but expression of this receptor may also extend to other cell types (Oumesmar et al., 1997). Oligodendrocyte progenitorcells may be heterogeneous in their antigenic profile (Spassky et al., 1998): the definition of further markers for these cells will help clarify this. AN2-positive cells isolated from glial cultures by immunopanning differentiated into MAG-positive oligodendrocytes in vitro, thus confirming that AN2-positive cells in this case can be termed oligodendrocyte progenitors. Recent experiments in which the AN2-positive cells in myelinating aggregate cultures are lysed with AN2 antibody and complement demonstrate that elimination of this cell population inhibits the synthesis of myelin proteins MBP and myelin oligodendrocyte glycoprotein (MOG). This shows that the AN2 antigen-expressing cells are essential for myelination (J. Shi and J. Trotter, unpublished results). The peak of AN2 expression in developing brain coincides with myelination. However, these Western blots as well as AN2 staining on sections of developing murine brain demonstrate that AN2 is expressed as early as embryonic day 14, well before myelination starts. Whether AN2 antigen-positive cells, especially at these early developmental times, represent committed oligodendrocytelineage cells or include cells with a broader developmental potential is still not determined.

\section{Carbohydrate residues including glycosaminoglycan chains may endow the AN2 antigen with additional biological properties}

Biochemical experiments showed that AN2 comprises a core protein of $\sim 300 \mathrm{kDa}$ with attached $\mathrm{N}$-glycoresidues (and probably O-glycoresidues), resulting in a molecular mass of $\sim 330 \mathrm{kDa}$. A subpopulation of the antigen expresses GAG chains. The presence of these carbohydrate epitopes may thus endow the antigen with additional biological properties.

The immunoaffinity-isolated AN2 antigen from brain (as well as from Oli-neu; data not shown) expresses the L2/HNK-1 carbohydrate epitope that is expressed by subpopulations of many cell adhesion molecules, including N-CAM, MAG, L1, and Tenascin-R, and has been shown to play a role in adhesion (Krüse et al., 1984; Keilhauer et al., 1985; Künemund et al., 1988). This observation supports a putative function of AN2 as an adhesion molecule.

\section{The AN2 antigen is a permissive substrate for attachment and process outgrowth of oligodendrocytes and granule cell neurons but is unfavorable for astrocytes}

Although oligodendrocytes and granule cell neurons did not distinguish between AN2 and PORN substrates, after $24 \mathrm{hr}$ astrocytes leave the AN2 substrate by either migration or detachment and remain solely on the PORN-coated areas. The physiological correlate of this observation is unclear. This behavior is not caused by slow digestion of the substrate by astrocyteassociated enzymes, because staining with antibodies demon- 
strated the persistence of AN2 antigen at the time when the grid-like pattern of astrocytes had formed. These results suggest that in the case of astrocytes an initial adhesion develops over time into a nonpermissive interaction.

Cerebellar granule cells extend long neurites on AN2-coated as well as AN2-free areas of the coverslip, demonstrating that the antigen supports neurite outgrowth from these cells. This observation is compatible with the expression of the AN2 protein by oligodendrocyte progenitor cells, which in contrast to more mature oligodendrocytes are thought to be a favorable substrate for growing neurites (for review, see Schwab et al., 1993; Filbin, 1995). The biological significance of the adhesion of both AN2positive and AN2-negative oligodendrocytes to the AN2 substrate and the demonstration of receptors for AN2 on different cells are topics for future research.

\section{A role for the AN2 antigen in the migration of oligodendrocyte precursor cells}

Oligodendrocyte progenitor cells migrate over long distances to reach the axonal tracts that they subsequently myelinate. In vitro and in vivo studies suggest that progenitor cells defined by the expression of gangliosides as well as the PDGF- $\alpha$-receptor are migratory, whereas more differentiated cells expressing $\mathrm{O} 4$ and with a more complex morphology are no longer migratory (for review, see Kiernan and ffrench-Constant, 1993). Elegant experiments in which these two stages of the lineage were separately isolated and transplanted into Shiverer mice demonstrated extensive migration of the progenitor cells away from the injection site, whereas O4-positive, galactocerebroside-negative cells showed only limited migration (Warrington et al., 1993).

The Oli-neu cell line resembles primary oligodendrocyte precursor cells in migratory behavior and axonal interaction in vivo and in vitro (Fok-Seang et al., 1995; Jung et al., 1995). The Oli-neu cells are migratory in our assays, as well as in time lapse studies (data not shown). In contrast, only the migratory precursor cells leave aggregates of primary cells. These migrating cells are almost all AN2 positive and have a simple bipolar or tripolar morphology. Such murine progenitor cells are less polarized than their rat counterparts, in agreement with the observations of Milner et al. (1996). Their migration was most pronounced in the presence of both bFGF and PDGF, as reported by others (Milner et al., 1996, 1997). Both growth factors have been shown to promote division and migration of progenitor cells (Noble et al., 1988; Armstrong et al., 1990; Bögler et al., 1990; McKinnon et al., 1990, 1993; Milner et al., 1996, 1997), and PDGF is additionally chemotactic for oligodendrocyte progenitors (Armstrong et al., 1990). Differentiation results in a cessation of both proliferation and migration (Pfeiffer et al., 1993). However, the results of Milner et al. (1996, 1997) demonstrate that oligodendrocyte precursors still migrate even if their proliferation is inhibited by antimitotic agents.

Polyclonal AN2 antibodies substantially reduced the migration of cells from aggregates of both Oli-neu cells and primary cells. The same antibodies did not affect the proliferation of the cells as shown by bromodeoxyuridine uptake (data not shown). Binding of the AN2 monoclonal antibody to its epitope does not alter migration, because this was unaffected by the addition of the antibody. Polyclonal IgG antibodies against F3, which bind to native oligodendrocyte progenitor cells and oligodendrocytes (Koch et al., 1997) and stain all Oli-neu cells, did not affect the migration of Oli-neu cells on poly-L-lysine. These controls thus demonstrate that the effects with polyclonal AN2 antibodies are specific and do not arise from simply binding and cross-linking just any cell-surface antigen.

Migration is a complex phenomenon, involving an interplay between adhesive and de-adhesive forces and changes in the cytoskeleton (Sheetz et al., 1998). The role of integrins in oligodendrocyte migration has been investigated, and it was established that $\alpha \mathrm{v} \beta 1$ plays a role in migration on astrocyte ECM (Milner et al., 1996). However, in addition to the integrins, other molecules must be involved because migration was never completely blocked with antibodies against integrins.

Our results suggest that the AN2 antigen is involved, but the precise role of the protein in migration of progenitor cells remains a topic for future research. The leading process of O-2A progenitor cells has been likened to a neuronal growth cone. The intense staining at the tips of the filopodia, regions of the cell where focal adhesions are concentrated, as well as the resistance of the antigen to complete detergent extraction, suggests that the AN2 protein may interact with the cell cytoskeleton. It is also possible that the AN2 antigen associates with integrins, and this association is perturbed by the antibody binding, resulting in an inhibition of migration.

\section{Identity of the AN2 antigen}

The antigen we have defined shows many similarities to the NG2 proteoglycan, which is also expressed by subpopulations of immature cells, including oligodendrocyte progenitor cells (Stallcup and Beasley, 1987; for review, see Levine and Nishiyama, 1996). A striking difference between the AN2 antigen and the NG2 proteoglycan is seen when the purified antigens are used as substrates for neuronal growth. On an AN2 substrate, cerebellar granule cells adhere and extend processes, whereas in contrast, NG2 is nonpermissive for attachment and neurite outgrowth from cerebellar neurons (Dou and Levine, 1994). The nonpermissive effects of NG2 even override the potent growthpromoting effects of L1 or laminin for cerebellar neurons, when L1 or laminin is presented with NG2 as a mixed substrate.

The human melanocyte glycoprotein, which has been cloned recently (Pluschke et al., 1996), exhibits sequence similarity to the rat NG2 proteoglycan (Nishiyama et al., 1991), with an overall homology at the amino acid level of $81 \%$. The NG2 antigen possesses several of the recently described laminin-neurexin-sex hormone-binding globulin domains (Missler and Südhof, 1998). The identity of the AN2 protein and its possible relationship to this family will be established by detailed molecular analysis.

\section{REFERENCES}

Amberger VR, Avellanan-Adalid V, Hensel T, Baron-Van Evercooren A, Schwab M (1997) Oligodendrocyte-type 2 astrocyte progenitors use a metalloendoprotease to spread and migrate on CNS myelin. Eur J Neurosci 9:151-162.

Armstrong RC, Harvarth L, Dubois-Dalq ME (1990) Type 1 astrocytes and oligodendrocyte Type 2 astrocyte glial progenitors migrate toward distinct molecules. J Neurosci Res 27:400-407.

Austyn JM, Gordon S (1981) F4/80, a monoclonal antibody directed specifically against the mouse macrophage. Eur J Immunol 11:805-815. Avellana-Adalid V, Nait-Oumesmar B, Lachapelle F, Baron-Van Evercooren A (1996) Expansion of rat oligodendrocyte progenitors into proliferative "oligospheres" that retain differentiation potential. J Neurosci Res 45:558-570.

Barres BA, Hart IK, Coles HSR, Burne JF, Voyvodic JT, Richardson WD, Raff MC (1992) Cell death and control of survival in the oligodendrocyte lineage. Cell 70:31-46.

Bögler O, Wren D, Bartlett SC, Land H, Noble M (1990) Cooperation between two growth factors promotes extended self-renewal and inhibits differentiation of oligodendrocyte-type-2-astrocyte $(\mathrm{O}-2 \mathrm{~A})$ progenitor cells. Proc Natl Acad Sci USA 76:514-517. 
Cammer W, Zhang H (1996) Ganglioside GD3 in radial glia and astrocytes in situ in brains of young and adult mice. J Neurosci Res 46:18-23.

Dou C-L, Levine JM (1994) Inhibition of neurite growth by the NG2 chondroitin sulphate proteoglycan. J Neurosci 14:7616-7628.

Doyle JP, Colman DR (1993) Glial-neuron interactions and the regulation of myelin formation. Curr Opin Cell Biol 5:779-785.

Einheber S, Zanazzi G, Ching W, Scherer S, Milner T, Peles E, Salzer LJ (1997) The axonal membrane protein Caspr, a homologue of Neurexin IV, is a component of the septate-link paranodal junctions that assemble during myelination. J Cell Biol 139:1495-1506.

Elbein AD (1981) The tunicamycins: useful tools for studies on glycoproteins. Trends Biochem Sci 6:219-221.

Faissner A, Kruse J (1990) J1/Tenascin is a repulsive substrate for central nervous system neurons. Neuron 5:627-637.

Faissner A, Teplow DW, Kübler D, Keilhauer G, Kinzel V, Schachner M (1985) Biosynthesis and membrane topography of the neural cell adhesion molecule L1. EMBO J 4:3105-3113.

Filbin MT (1995) Myelin-associated glycoprotein: a role in myelination and in the inhibition of regeneration. Curr Opin Neurobiol 5:588-595.

Fok-Seang J, Mathews GA, ffrench-Constant C, Trotter J, Fawcett JW (1995) Migration of oligodendrocyte precursors on astrocytes and meningeal cells. Dev Biol 171:1-15.

Fruttiger M, Montag D, Schachner M, Martini R (1995) Crucial role for the myelin-associated glycoprotein in the maintenance of axon-myelin integrity. Eur J Neurosci 7:511-515.

Hall A, Giese NA, Richardson WD (1996) Spinal cord oligodendrocytes develop from ventrally derived progenitor cells that express PDGF alpha-receptors. Development 122:4085-4094.

Hardy RJ, Friedrich VL (1996) Oligodendrocyte progenitors are generated throughout the embryonic mouse brain, but differentiate in restricted foci. Development 122:2059-2069.

Jung M, Krämer E, Grzenkowski M, Tang K, Blakemore W, Aguzzi A, Khazaie K, Chichlia K, von Blankenfeld G, Kettenmann H, Trotter J (1995) Lines of murine oligodendroglial precursor cells immortalized by an activated neu tyrosine kinase show distinct degree of interaction with axons in vitro and in vivo. Eur J Neurosci 7:1245-1265.

Keilhauer G, Faissner A, Schachner M (1985) Differential inhibition of neuron-neuron, neuron-astrocyte and astrocyte-astrocyte adhesion by L1, L2 and N-CAM antibodies. Nature 316:728-730.

Kiernan BW, ffrench-Constant C (1993) Oligodendrocyte precursor (O-2A progenitor cell) migration: a model system for the study of cell migration in the developing central nervous system. Development [Suppl] 219-225.

Koch T, Brugger T, Bach A, Gennarini G, Trotter J (1997) Expression of the immunoglobulin superfamily cell adhesion molecule $\mathrm{F} 3$ by oligodendrocyte-lineage cells. Glia 19:199-212.

Krüse J, Mailhammer R, Wernecke H, Faissner A, Sommer I, Goridis C, Schachner M (1984) Neural cell adhesion molecules and myelinassociated glycoprotein share a common carbohydrate moiety recognised by monoclonal antibodies L2 and HNK-1. Nature 311:153-155.

Künemund V, Jungalwala FB, Fischer G, Chou DKH, Keilhauer G, Schachner M (1988) The L2/HNK-1 carbohydrate of neural cell adhesion molecules is involved in cell interactions. J Cell Biol 106:213-223.

Lachapelle F, Gumpel M, Baulac M, Jacque C, Duc P, Baumann N (1983-1984) Transplantation of CNS fragments into the brain of shiverer mutant mice: extensive myelination by implanted oligodendrocytes. I. Immunohistochemical studies. Dev Neurosci 6:325-334.

Laemmli UK (1970) Cleavage of structural proteins during the assembly of the head of bacteriophage T4. Nature 227:680-685.

Levine JM, Nishiyama A (1996) The NG2 chondroitin sulfate proteoglycan: a functional proteoglycan associated with immature cells. Perspect Dev Neurobiol 3:245-259.

Levison SM, Goldman JE (1993) Both oligodendrocytes and astrocytes develop from progenitors in the subventricular zone of postnatal rat forebrain. Neuron 10:201-212.

Li C, Tropak MB, Gerlai R, Clapoff S, Abramow-Newerly W, Trapp B, Peterson A, Roder J (1994) Myelination in the absence of myelinassociated glycoprotein. Nature 369:747-750.

Lubetzki C, Demerens C, Angelade P, Villaroya H, Frankfurter A, Lee VMY, Zalc B (1993) Even in culture, oligodendrocytes myelinate solely axons. Proc Natl Acad Sci USA 90:6820-6824.

Malek-Hedayat S, Rome LH (1994) Expression of a $\beta$-1 related integrin by oligodendrocytes in primary culture: evidence for a functional role in myelination. J Cell Biol 124:1039-1046.
Martini R, Schachner M (1997) Molecular basis of myelin formation as revealed by investigations on mice deficient in glial cell surface molecules. Glia 19:298-310.

McKinnon RD, Matsui T, Dubois-Dalcq M, Aaronson SA (1990) FGF modulates the PDGF-driven pathway of oligodendrocyte development. Neuron 5:603-614.

McKinnon RD, Smith C, Behar T, Smith T, Dubois-Dalcq M (1993) Distinct effects of bFGF and PDGF on oligodendrocyte progenitor cells. Glia 7:245-254.

Milner R, ffrench-Constant C (1994) A developmental analysis of oligodendroglial integrins in primary cells: changes in $\alpha \mathrm{v}$-associated $\beta$ subunits during development. Development 120:3497-3506.

Milner R, Edwards G, Streuli C, ffrench-Constant C (1996) A role for migration of the $\alpha \mathrm{v} \beta 1$ integrin expressed on oligodendrocyte precursors. J Neurosci 16:7240-7252.

Milner R, Anderson HJ, Rippon RF, McKay JS, Franklin RJM, Marchionni MA, Reynolds R, ffrench-Constant C (1997) Contrasting effects of mitogenic growth factors on oligodendrocyte precursor migration. Glia 19:85-90.

Montag D, Giese KP, Bartsch U, Martini R, Lang Y, Blüthmann H, Karthigasan J, Kirschner DA, Wintergerst ES, Nave K-A, Zielasek J, Toyka KV, Lipp H-P, Schachner M (1994) Mice deficient for the myelin-associated glycoprotein show subtle abnormalities in myelin. Neuron 13:229-246.

Missler M, Südhof TC (1998) Neurexins: three genes and 1001 products. Trends Genet 14:20-26.

Nishiyama A, Dahlin KJ, Prince JT, Johnston SR, Stallcup WB (1991) The primary structure of NG2, a novel membrane-spanning proteoglycan. J Cell Biol 114:359-371.

Noble M, Murray K, Stroobant P, Waterfield M, Riddle P (1988) Platelet-derived growth factor promotes division and motility and inhibits premature differentiation of the oligodendrocyte type 2 astrocyte progenitor cell. Nature 333:560-565.

Noll E, Miller RH (1993) Oligodendrocyte progenitors originate at the ventral ventricular zone dorsal to the ventral midline in the embryonic rat spinal cord. Development 118:563-573.

Ono K, Yasui Y, Rutishauser U, Miller RH (1997) Focal ventricular origin and migration of oligodendrocyte precursors into the chick optic nerve. Neuron 19:283-292.

Oumesmar BN, Vignais L, Baron-Van Evercooren A (1997) Developmental expression of platelet-derived growth factor alpha-receptor in neurons and glial cells of the mouse CNS. J Neurosci 17:125-139.

Pfeiffer SE, Warrington AE, Bansal R (1993) The oligodendrocyte and its many cellular processes. Trends Cell Biol 3:191-197.

Pluschke G, Vanek M, Evans A, Dittmar T, Schmid P, Itin P, Filardo EJ, Reisfeld RA (1996) Molecular cloning of a human melanomaassociated chondroitin sulfate proteoglycan. Proc Natl Acad Sci USA 93:9710-9715.

Poltorak M, Sadoul R, Keilhauer G, Landa C, Fahrig T, Schachner M (1987) The myelin-associated glycoprotein (MAG), a member of the L2/HNK-1 family of neural cell adhesion molecules is involved in neuron-oligodendrocyte and oligodendrocyte-oligodendrocyte interaction. J Cell Biol 105:1893-1899.

Pringle N, Richardson WD (1993) A singularity of PDGF alphareceptor expression in the dorsoventral axis of the neural tube may define the origin of the oligodendrocyte lineage. Development 117:525-533.

Pringle NP, Mudhar HS, Collarini EJ, Richardson WD (1992) PDGFreceptors in the rat CNS: during late neurogenesis, PDGF alphareceptor expression appears to be restricted to glial cells of the oligodendrocyte lineage. Development 115:535-551.

Rathjen FG, Schachner M (1984) Immunocytological and biochemical characterization of a new neuronal cell surface component (L1 antigen) which is involved in cell adhesion. EMBO J 3:1-10.

Reynolds R, Wilkin GP (1988) Development of macroglial cells in rat cerebellum II. An in situ immunohistochemical study of oligodendroglial lineage from precursor to mature myelinating cell. Development 102:409-425.

Schachner M, Kim S, Zehnle R (1981) Developmental expression in central and peripheral nervous system of oligodendrocyte cell surface antigens (O antigens) recognized by monoclonal antibodies. Dev Biol 83:328-338.

Schnitzer J, Schachner M (1981) Developmental expression of cell typespecific markers in mouse cerebellar cells in vitro. J Neuroimmunol 1:471-487. 
Schwab ME, Kapfhammer JP, Bandtlow C (1993) Inhibitors of neurite growth. Annu Rev Neurosci 16:565-597.

Seilheimer B, Schachner M (1988) Studies of adhesion molecules mediating interactions between cells of peripheral nervous system indicate a major role for L1 in mediating sensory neuron growth on Schwann cells in culture. J Cell Biol 107:341-351.

Seilheimer B, Persohn E, Schachner M (1989) Antibodies to the L1 adhesion molecule inhibit Schwann cell ensheathment of neurones in vitro. J Cell Biol 109:3095-3103.

Sheetz MP, Felsenfeld DP, Galbraith CG (1998) Cell migration: regulation of force on extracellular matrix-integrin complexes. Trends Cell Biol 8:51-54.

Small RK, Riddle P, Noble M (1987) Evidence for migration of oligodendrocyte-type-2 astrocyte progenitor cells into the developing rat optic nerve. Nature 328:155-157.

Sommer I, Schachner M (1981) Monoclonal antibodies (O1 to O4) to oligodendrocyte cell surfaces: an immunocytological study in the central nervous system. Dev Biol 83:311-327.

Spassky N, Goujet-Zalc C, Parmantier E, Olivier C, Martinez S, Ivanova A,
Ikenaka K, Macklin W, Cerruti I, Zalc B, Thomas J-L (1998) Multiple restricted origin of oligodendrocytes. J Neurosci 18:8331-8343.

Springer T, Galfre G, Secher DS, Milstein C (1979) Mac-1: a macrophage differentiation antigen identified by monoclonal antibody. Eur J Immunol 9:301-306.

Stallcup WB, Beasley L (1987) Bipotential glial precursor cells of the optic nerve express the NG2 proteoglycan. J Neurosci 7:2737-2744.

Trotter J, Schachner M (1989) Cells positive for the O4 surface antigen isolated by cell sorting are able to differentiate into astrocytes or oligodendrocytes. Dev Brain Res 46:115-122.

Trotter J, Bitter-Suermann D, Schachner M (1989) Differentiationregulated loss of the polysialylated embryonic form and expression of the different polypeptides of the neural cell adhesion molecule $(\mathrm{N}$ CAM) by oligodendrocytes and myelin. J Neurosci Res 22:369-383.

Warrington AE, Barbarese E, Pfeiffer SE (1993) Differential myelinogenic capacity of specific developmental stages of the oligodendrocyte lineage upon transplantation into hypomyelinating hosts. J Neurosci Res 34:1-13.

Wysocki LJ, Sato VL (1978) "Panning" for lymphocytes: a method for cell selection. Proc Natl Acad Sci USA 75:2844-2848. 